\title{
Lower to Middle Ordovician trilobite faunas along the Ural border of Baltica
}

\author{
HELE PÄRNASTE \& JAN BERGSTRÖM ${ }^{\dagger}$
}

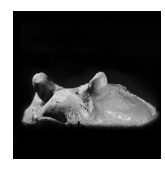

\begin{abstract}
Recent revision of the Ölandian trilobite faunas in Baltoscandia and the Ural Mountains throws new light on the development of the trilobite faunas in Baltica and possible migration links to surrounding terranes. The trilobite assemblages of 104 genera on the Uralian side of Baltica show different development patterns for the south and north through the Tremadocian to the Darriwilian. The oldest Uralian trilobites - disputably of latest Cambrian or earliest Ordovician age - arrived probably from the Siberian and Kazakh terranes being represented by mostly endemic genera such as Kujandaspis and Jdyia, but also with pandemic Akoldinioidia and Micragnostus. The following Kidryasian, Kolnabukian and Kuagachian faunas change gradually to show increasing difference between the sections in the South Urals and those in the northern Polar Urals or Pay-Khoy. In Kidryasian the olenids dominate in the South Urals as they do in many other regions during the early Tremadocian. The Kolnabukian trilobites represent the most diverse trilobite association in the region, and are comparable to the Ceratopyge fauna. The Kuagachian fauna contains a few additional elements, increasing the difference between south and north but with reduced generic diversity. The routes of faunal exchange are modified too. Thus during the Early Ordovician migration between the Uralian side of Baltica and the Baltoscandia, Kazakh and Altai-Sayan terranes becomes more important than that between the Uralian side of Baltica and the Siberia, North and South China plates. The Darriwilian Karakol-Mikhailovskian faunal association shows a clear separation between north and south Urals with the former region, as in Baltoscandia, dominated by asaphids, while in south a reefal illaenid-cheirurid association of Laurentian genera occurs. This is rather intriguing given the widely accepted palaeogeographical disparate position and latitude of Laurentia at the time. Key words: Ordovician, trilobites, Urals, Baltica, palaeogeography.
\end{abstract}

PÄRNASTE, H. \& BERGSTRÖM, J. 2014. Lower to Middle Ordovician trilobite faunas along the Ural border of Baltica. Bulletin of Geosciences 89(2), 431-450 (5 figures, 1 table). Czech Geological Survey, Prague. ISSN 1214-1119. Manuscript received May 3, 2013; accepted in revised form April 2, 2014; published online May 19, 2014; issued May 19, 2014.

Helje Pärnaste, Institute of Geology, Tallinn University of Technology, Ehitajate tee 5, Tallinn 19086, Estonia; helje.parnaste@ttu.ee•Jan Bergström, in memoriam

Most Baltic Early to Middle Ordovician trilobites are endemic with a prevalence of asaphid genera and hence known as the Asaphid Province (Whittington 1963, Fortey \& Cocks 2003, Bergström et al. 2013, Pärnaste \& Bergström 2013). The Uralian border of Baltica is less well known. Even though what faunal lists exist, suggest some similarity between the east and west of Baltica. The aim of this study is (1) to compare the development of trilobite faunas along the Uralian side of Baltica, and (2) to compare the generic composition of the earliest faunas with the Baltoscandian side and with those of neighbouring terranes in order to assess possible migration routes for the earliest Uralian trilobite faunas.

\section{Material and methods}

Based on available photographs and descriptions, all early published trilobite data from the Urals have been assem- bled and revised. These include the work of Lermontova \& Razumovskiy (1933), Weber (1948), Balashova (1961), Burskiy (1966, 1970), Antsygin (1973, 1977, 1978, 1991, 1993, 2001), and Antsygin et al. (1977). In comparing published faunas known from Baltoscandian side of Baltica with those of the Uralian side, it is obvious that the latter are relatively smaller in number possibly because of fewer studies or because publications are available only in Russian. All together about 220 species belonging to 104 genera from the latest Cambrian to the middle Darriwilian are listed in Bergström et al. (2013).

We use the genus level here for our analyses to investigate the development and variability of the trilobite faunas in an extended area such as the Urals together with Pay-Khoy and Vaygach in the north, extending south to the Mugodzhars in Aktyube Region and northwestern Kazakhstan. The faunas of different regions are listed separately. We follow the stratigraphical data of Antsygin (2001) to 


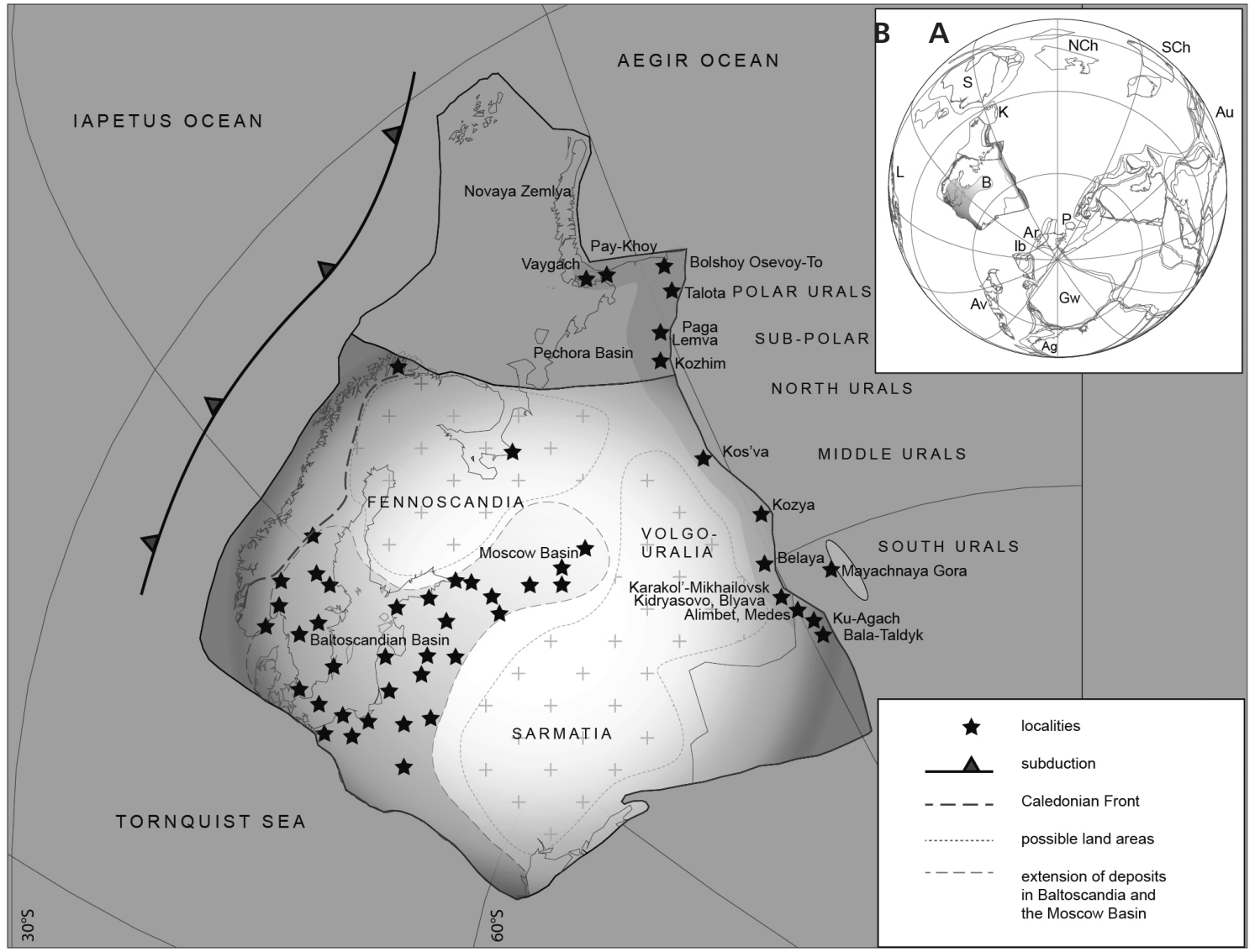

Figure 1. The Baltica Palaeoplate (A - global view; B - zoom in) with its complex borders and development of restricted marine sedimentary rocks in Baltoscandia in the west, the Moscow Basin deep within the plate, and the Cis-Ural belt in the east in its suggested position at about transition from Tremadocian to Floian (map generated using the T.H. Torsvik's GIS-oriented software from 2009, BugPlates: linking biogeography and palaeogeography). Abbreviations: Ag - Argentina; Av - Avalonia; Ar - Armorica; Au - Australia; B - Baltica; Gw - Gondwana; Ib - Iberia; K - Kara; L - Laurentia; NCh - North China; P - Perunica; S - Siberia; SCh - South China.

avoid mixing units introduced by authors dealing with other aspects than trilobites. The comparison presented here embodies our revision of the Baltoscandian taxa in Pärnaste et al. (2013).

\section{Geological setting}

The Lower Palaeozoic Baltica Palaeoplate (Cocks \& Torsvik 2005) comprises the East European Craton as its core with three major crustal segments Fennoscandia, Sarmatia and Volgo-Uralia that collided between $c a 2.0$ and $1.7 \mathrm{Ga}$ (Bogdanova et al. 2008), and the Pechora Basin that became accreted to Baltica in the late Vendian as a part of the Timanide Orogeny (Bogolepova \& Gee 2004, O'Leary et al. 2004, Gee et al. 2008). The Kara block has been interpreted as a part of Baltica (Fig. 1A; e.g. Lorenz et al. 2008) or as an independent terrane (e.g. Metelkin et al. 2000, 2005; Torsvik \& Andersen 2002; Cocks \& Torsvik 2005) between Baltica and Siberia in the Ordovician Period. During the Cambrian and Ordovician, Baltica rotated through more than 120 degrees and drifted northwards from high to low palaeolatitudes. Thus the Uralian side that initially faced the Gondwana in high latitude changed its orientation to become more or less north-south oriented by the beginning of the Floian with its northern areas reaching into temperate climate zone (Fig. 1B).

In the Urals, the Ordovician facies are approximately meridional, as this mountain range is oriented today. The alluvial deposits in the westernmost facies belt are replaced to the east by shelf sediments followed by deep oceanic and rift sediments, which are allochthonous (e.g. Varganov et al. 1973, Savelieva \& Nesbitt 1996, Bogolepova \& Gee 2004, Ryazantsev et al. 2008). The shore-most facies, the Eletsk [Eletskaya] contains a cyclic succession of various sandstones alternating with conglomerates (Manitanyrd Formation) of mainly continental and coastal shallow-water deposits, mostly without trilobites (Bogolepova \& Gee 2004). Eastwards, the Sakmara-Lemva [Lemvinskaya] facial zone consists of shelf sediments of the Pogurey [Pogureyskaya] Formation in the north and the Kidryas [Kidryasovskaya] Formation in the south, where trilobites 
are known from the upper Cambrian onwards. This facial zone is a relatively narrow region with complicated relief, often showing active hydrodynamic conditions (i.e. highly variable thickness of deposits). The upper Cambrian and Lower-Middle Ordovician succession comprises the following regional stages (horizons): Khmelev [Khmelevskiy], Kidryas [Kidryasovskiy], Kolnabuk [Kolnabukskiy], Kuagach [Kuagachskiy], Karakol-Mikhailovsk (Fig. 2; Varganov et al. 1973, Antsygin 2001). The Pogurey [Pogureyskaya Svita] Formation is replaced by the Kibatin [Kibatinskaya] and Grubein [Grubeinskaya] formations. The latter is characterized by a thick complex of deep-water shales alternating with volcanic rocks representing a continental slope facies. During the Middle and Late Ordovician the deeper water conditions reach to the Sakmara-Lemva Zone. Most of the known trilobites come from this Sakmara-Lemva facial Zone.

The Tremadocian trilobites also occur on Pay-Khoy hills, on the Yugorsky Peninsula near the northern end of the Urals at the Kara Sea. Four trilobite beds were recognized in the Sokoli Regional Stage [Sokoliyskiy Horizon]: (1) Synthrophopsis magna and Dikelokephalina beds, (2) Nyaya and Tersella beds, (3) Apatokephalus serratus beds, and (4) Megalaspides beds (Fig. 2; Bondarev et al. 1970, Burskiy 1970). The following Tetragraptus approximatus, and the Phyllograptus aff. densus and Eorobergia nericensis beds of the Nelidov Regional Stage [Nelidovskiy Horizon] represent broadly the Floian Stage, and Megistaspis limbata and Trigonograptus ensiformis beds the Dapingian Stage, possibly reaching to the lower Darriwilian Stage. These beds belong to the Amdermin facial zone. The younger sediments with upper Darriwilian and younger Ordovician faunas occur on the southern side of the Yugorsky Peninsula on the coast of the Pechora Sea and on the islands of Vaygach and Novaya Zemlya and are thus named the Vaygach and Novaya Zemlya facial zones (Bondarev et al. 1970).

\section{Khmelev Regional Stage}

The Khmelevian trilobites (Table 1A) Akoldinioidia (det. as Eoshumardia Hupé, 1953 in Antsygin 2001), Jdyia and Kujandaspis together with Micragnostus have been regarded as being of Cambrian age (Antsygin 2001, Bogolepova \& Gee 2004). The hystricurid Jdyia is endemic to the Urals, while Micragnostus is widely distributed around Gondwana and the Kazakh terranes since the upper Cambrian (Table 1B). The latter is recorded from Sub-Polar Urals (Bogolepova \& Gee 2004) and South Urals (Antsygin 2001). The shumardiid Akoldinioidia occurs in the upper Cambrian of North China, South China, and Australia terranes and reaches to the Bolivia and Oaxaca (Mexico) regions in Tremadocian (Fig. 3; see revised list in Peng

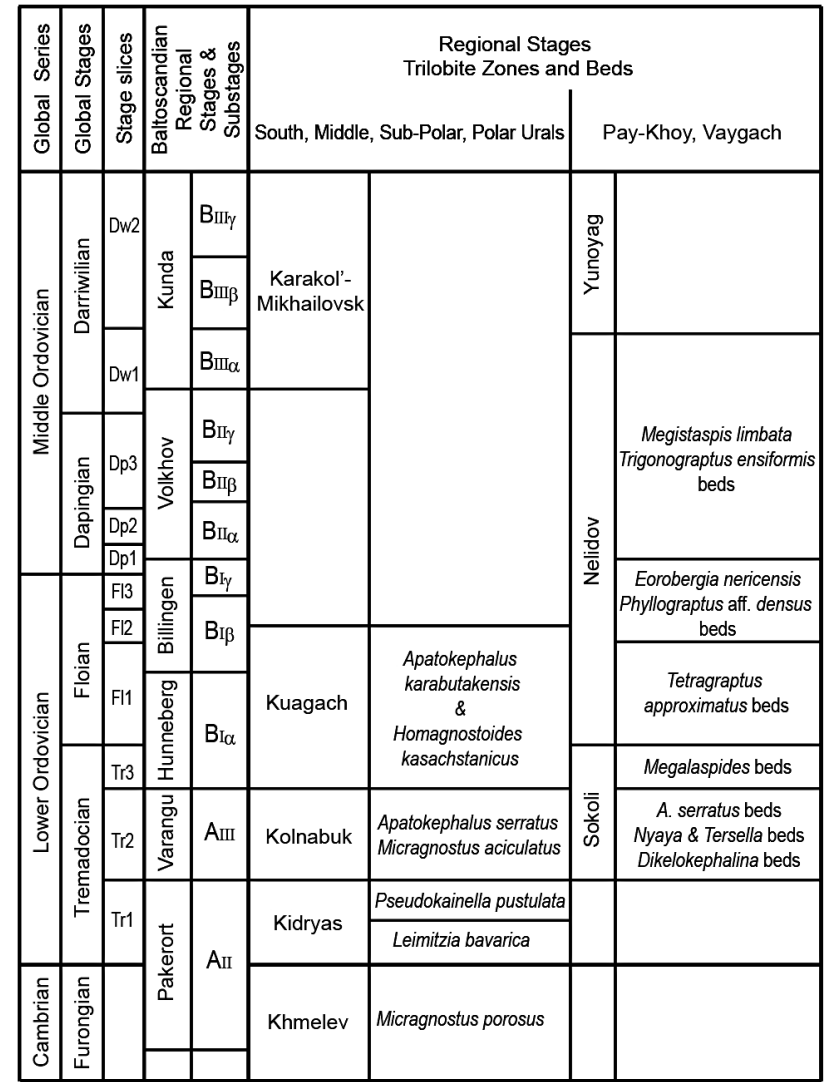

Figure 2. Correlation chart for the lower part of the Ordovician in Baltica. The correlation follows our earlier papers (Pärnaste \& Viira 2012, Bergström et al. 2013, Pärnaste et al. 2013), where the Baltoscandian trilobite zones are compared with the recent data on graptolite (Maletz \& Ahlberg 2011) and conodont zonation (Bergström \& Löfgren 2009), and the global chronostratigraphy (Bergström et al. 2009). The stratigraphical framework of Urals is following that in Antsygin (1977, 2001; see also Bergström et al. 2013).

1992, Zhu \& Peng 2006). The eulomid Kujandaspis (including species of Ketyna; see for discussion on taxonomy in Rushton et al. 2002) is known from the upper Cambrian of the Kazakh terranes (Ivshin 1956, Apollonov \& Chugaeva 1983), from Severnaya Zemlya (Rushton et al. 2002) and the Kulyumbe and Chopko rivers in the Siberia Plate (Fig. 3; Rozova 1968, Varlamov et al. 2006, Lazarenko et al. 2011) that possibly faced to the north of the Baltica Plate at that time (Fig. 1A; Cocks \& Torsvik 2002). This is one of several pieces of evidence suggesting a possible Cambrian age of the Khmelev beds in the Urals and linking biogeographical connections between the listed terranes. The Khmelevian fauna may have arrived south through the Pechora Basin (Fortey \& Cocks 2003, fig. 14; Cocks \& Torsvik 2005, figs 5-6). Alternatively these allochthonous belts belonging to the Sakmara Zone (Guberlya microcontinent in Ryazantsev et al. 2008, fig. 11) possibly drifted differently from the main body of Baltica and were closer to Siberia in the lower latitudes during the Khmelevian or 


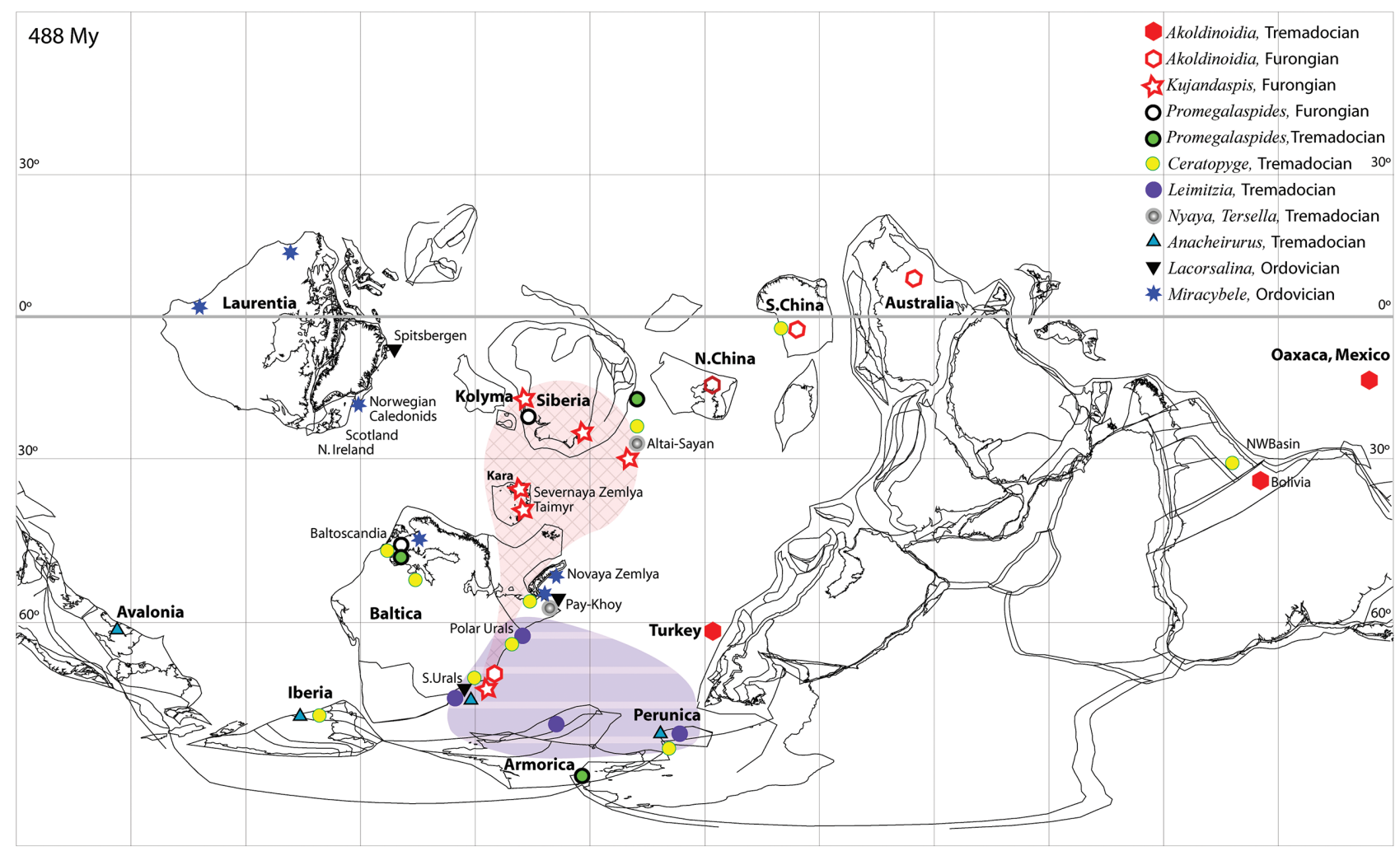

Figure 3. Global reconstruction in early Ordovician (488 Ma) time (map generated using the T.H. Torsvik's GIS-oriented software from 2009 , BugPlates: linking biogeography and palaeogeography) to show distribution of selected genera regionally restricted to certain areas. The chequered shading marks the occurrences of Kujandaspis, while lined shading that of Leimitzia.

the fauna migrated via the Kazakh terranes ( $c f$. palaeogeographic situation in Fortey \& Cocks 2003, fig. 14). The overlying beds with a hungaiid Leimitzia are most probably of Ordovician age, as Leimitzia is common in the Lower Tremadocian of Bavaria (Fig. 3; Sdzuy et al. 2001) and the Tremadocian of Perunica (Mergl 2006).

\section{Kidryas Regional Stage}

In the Tremadocian the most common trilobites in the Urals were olenids (Peltocare, Saltaspis, Triarthrus?), hungaiids (Leimitzia, Dikelokephalina), cyclopygids (Pricyclopyge, Tyrmancyclopyge), remopleuridids (Apatokephalus), trinucleoids (Orometopus), asaphids (Niobe), ceratopygids (Ceratopyge), shumardids (Akoldinioidia), and a possible hystricurid Jdyia (Antsygin 2001, pp. 111-113, table 1).

The Kidryasian trilobites represent at least most of the Lower Tremadocian fauna in the South and Polar Urals (Table 1A). All three genera known from the Sub-Polar and Polar Urals (Leimitzia, Jdyia, Dolgedola) also occur in the South (Fig. 4). Five olenid genera and one eulomid, one pterocephalid and one acrocephalitid are ptychopariids. Nearly thirty per cent of the genera belong to the Asaphida, with three remopleuridids, two asaphids, two hungaiids and one ceratopygid.

Of nineteen genera recorded from the Kidryasian of the South Urals, four are endemic (Alimbetaspis, Dolgedola, Jdyia, Medeselaspis) and nearly half of them are shared with Baltoscandia (Table 1B). A similar number of genera, but with slight variation in content, is recorded from the Tremadocian of Laurentia, Argentina, South China and Armorica plus Perunica. Of Furongian genera, only three of them show a wide distribution in the Urals during the Tremadocian (Micragnostus, Macropyge and Parabolinella). Parabolinella is known from Argentina, Avalonia, Baltoscandia, China, Tasmania and NE Laurentia where it occurs from Furongian to Tremadocian (Bao \& Jago 2000, Monti \& Confalonieri 2013, fig. 4). A remopleuridid Apatokephalus, which appears in Siberia by the end of Cambrian (Mansi Stage, Ogienko 1984; $c f$. correlation in Varlamov et al. 2006, fig. 19) is globally widely distributed on the Tremadocian terranes (for taxonomy see Ebbestad 1999). Its sister taxon Kainella extends from Argentina to Laurentia and Urals. The earliest asaphids, Promegalaspides and Niobe, which originate in Cambrian of Siberia or Baltoscandia (Fig. 3; Lazarenko et al. 2011, Pärnaste \& Bergström 2013) also arrive in the Uralian side of Baltica during the early Ordovician. The poorly known 

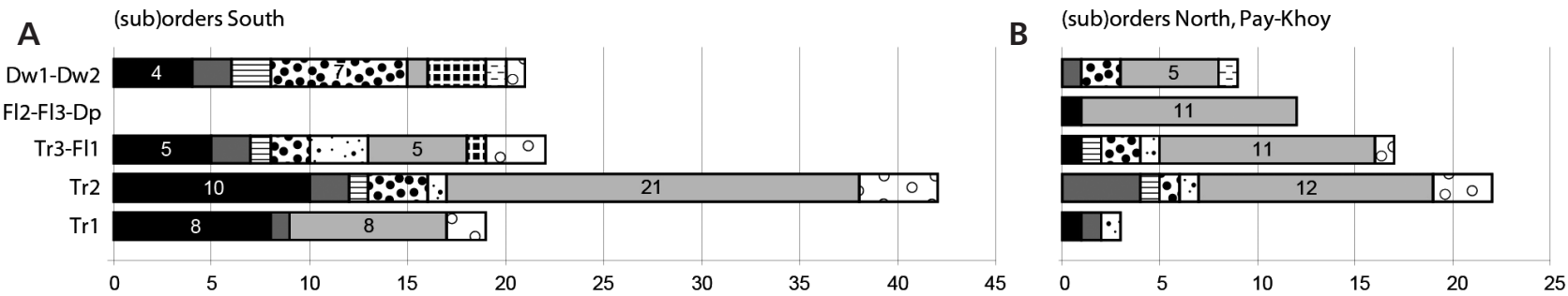

\section{C (sub)orders}

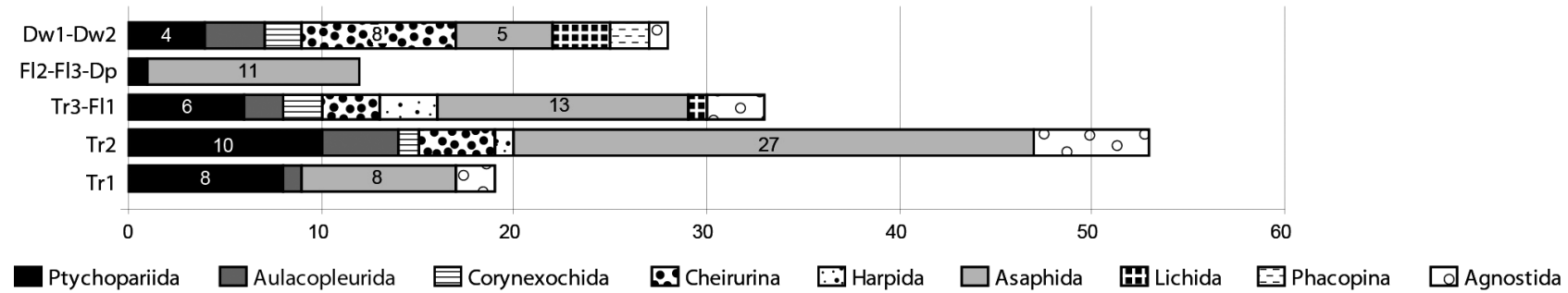

Figure 4. The generic composition of the Uralian trilobites presented in order or suborder level from Tremadocian to the Darriwilian to show differences in faunal development with possible palaeogeographical influence. - A - trilobites of South Urals, including those from Mugodzhars in Aktyube Region, northwestern Kazakhstan. $\bullet$ B - trilobites of Sub-Polar and Polar Urals, and areas collided in Cambrian - Pay-Khoy Peninsula and Vaygach Island. $\bullet \mathrm{C}-$ trilobites of both areas combined together.

Hystricurus is shared between Siberia and the Urals (Balashova 1961). Consequently, of fifteen non-endemic genera of the Kidryasian fauna over half of taxa (one agnostid, two ptychopariids and five asaphids) are of Cambrian origin.

\section{Kolnabuk and Sokoli Regional Stages}

The Middle Tremadocian Kolnabukian trilobite fauna is more diverse than the older fauna with fifty-three genera: forty-two of them are known from the Urals and twenty-two occur in Pay-Khoy, some of them being present in both last named areas (Fig. 4). Of Kidryasian genera nearly half extend into this stage, including the olenids (Table 1A). Newly appear the orders Phacopida (Cheirurina), Aulacopleurida, Cornexochida and Harpetida. While the number of ptychopariids remains nearly the same, the reverse is the case of the asaphids. The latter diversify remarkably amounting to fifty per cent of all genera. The new Asaphida families to appear are the Alsataspididae, Nileidae and Cyclopygidae. The ptychopariids also become more diverse with ten genera. Ceratopyge, Dikelokephalina, Nileus, Pricyclopyge and Micragnostus prevail. The morphology of trilobites all together shows a great variation in life style, indicating that they occupied various ecological niches from deeper water continental slope environments to the shelf areas similar to those in outer shelf in Baltoscandia (Bergström et al. 2013).

The trilobites of Synthrophopsis magna and Dikelokephalina beds from the Sokoli Stage are the oldest in Pay-Khoy hills on the Yugorsky Peninsula, possibly corresponding to the Kolnabuk Stage of the southern Urals
(Fig. 2, Table 1A; Antsygin 2001). The succeeding two beds with Nyaya and Tersella and with Apatokephalus serratus are also correlated with that stage, while the topmost Megalaspides Bed of the Sokoli Stage equates with the lowest Kuagachian of the South Urals. The first three beds seem to correspond to the Ceratopyge beds (Varangu Regional Stage; Tr2) in Baltoscandia and the fourth to the lower Hunnebergian Stage $(\sim \operatorname{Tr} 3)$. A comparison of the north (Pay-Khoy) and the south reveals that the number of genera is smaller, possibly because of limited collections, but the names are the same. Only one obscure taxon makes the difference - Asaphopsoides(?) for the S. magna and Dikelokephalina Bed. However, the beds with Nyaya and Tersella include seven of the fifteen genera not recorded from the south. Noteworthy is the absence of the ptychopariids (including olenids), which are well diversified in south. This can be explained by a limited range of sediments representing only the near-shore conditions in Pay-Khoy while the missing olenids come from the deeper water outer shelf. The Sokolian genera can be compared with Baltoscandia and Laurentia rather than with other regions (Table 1B). Nyaya and Tersella are related to the $\mathrm{Si}$ beria and Altai-Sayan Region.

Outside of Baltoscandia, Nyaya appears in the Nyaian Regional Stage in the lowest Ordovician of Siberia (Rozova 1968, 1977; Ogienko 1974, 1984; Gorovtsova \& Semenova 1977; for the latest correlation of the Cambrian-Ordovician boundary see Lazarenko et al. 2011). Together with Tersella it is known also from the lowest Ordovician in the Kuznetsk Alatau (Petrunina 1973, 1990), and from the Tremadocian Sokoli Stage of Pay-Khoy (Fig. 3; Burskiy 1970). Some questionable representatives from 
Table 1A. Genera / regions in Urals, and occurrences on other regions and terranes (Table 1B). Abbreviations: SU - South Urals; SPU - Sub-Polar Urals; PU - Polar Urals; PK - Pay-Khoy; MG - Mayachnaya Gora, SE Urals; St. - Stage; Fm. - Formation. Font styles are set as the italic to mark rare occurrence, the regular to mark common species, and the bold to mark abundant occurrences (Antsygin 2001). 1 - Khmelev St., SU, PU; 2 - Kidryas St., SU; 3 - Pogurey Fm., Kidryas St., PU; 4 - Kolnabuk St., SU; 5 - Kibatin Fm., Kolnabuk St., PU; 6 - Bredin beds (partly), MG; 7 - Synthrophopsis magna \& Dikelokephalina beds, Sokoli St, PK; 8 - Nyaya \& Tersella beds, Sokoli St., PK; 9 - Apatokephalus serratus beds, Sokoli St., PK; 10 - Megalaspides beds, Sokoli St., PK; 11 - Kuagach St., SU; 12 - Grubein Fm., Kolnabuk-Kuagach Sts., PU; 13 - Tetragraptus approximatus beds, Nelidov St., PK; 14 - Phyllograptus aff. densus \& Eorobergia nericensis beds, Nelidov St., PK; 15 - Megistaspis limbata \& Trigonograptus ensiformis beds, Nelidov St., PK; 16 - Bredin beds (partly), MG; 17 - Karakol'-Mikhailov St., SU; 18 - Karakol'-Mikhailov St., SPU \& PU.

\begin{tabular}{|c|c|c|c|c|c|c|c|c|c|c|c|c|c|c|c|c|c|c|c|}
\hline \multirow{2}{*}{$\begin{array}{c}\text { Trilobite families } \\
\text { \& Agnostida }\end{array}$} & & \multirow{2}{*}{$\frac{\mathrm{C}-\mathrm{O}}{1}$} & \multicolumn{2}{|c|}{$\operatorname{Tr} 1$} & \multicolumn{5}{|c|}{$\operatorname{Tr} 2$} & \multicolumn{5}{|c|}{ Tr3-F11 } & \multirow{2}{*}{$\begin{array}{c}\text { Fl2-3 } \\
14 \\
\end{array}$} & \multirow{2}{*}{$\begin{array}{l}\mathrm{Dp} \\
15\end{array}$} & \multicolumn{3}{|c|}{ Dw } \\
\hline & & & 2 & 3 & 4 & 5 & 6 & 7 & 8 & 9 & 10 & 11 & 12 & 13 & & & 16 & 17 & 18 \\
\hline Agnostida & Micragnostus Howell, 1935 & 1 & 1 & & 1 & & & & & & & & & & & & & & \\
\hline Eulomidae & Kujandaspis Ivshin, 1953 & 1 & & & & & & & & & & & & & & & & & \\
\hline Shumardiidae & Akoldinioidia Zhou \& Zhang, 1984 & 1 & & & & & & & & & & & & & & & & & \\
\hline Hungaiidae & Jdyia Antsygin, 2001 & 1 & 1 & 1 & & & & & & & & & & & & & & & \\
\hline Hystricuridae & Leimitzia Sdzuy, 1955 & & 1 & 1 & & & & & & & & & & & & & & & \\
\hline Agnostida & Geragnostus Howell, 1935 & & 1 & & 1 & & & 1 & 1 & & 1 & 1 & 1 & 1 & & & & 1 & \\
\hline Acrocephalitidae & Dolgedola Antsygin, 2001 & & 1 & 1 & & & & & & & & & & & & & & & \\
\hline Eulomidae & Lateuloma Dean, 1973 & & 1 & & & & & & & & & & & & & & & & \\
\hline Olenidae & Acerocarina Poulsen, 1952 & & 1 & & 1 & & & & & & & & & & & & & & \\
\hline Olenidae & Alimbetaspis Balashova, 1961 & & 1 & & 1 & & & & & & & & & & & & & & \\
\hline Olenidae & Jujuyaspis Kobayashi, 1936 & & 1 & & & & & & & & & & & & & & & & \\
\hline Olenidae & Parabolinella Brøgger, 1882 & & 1 & & 1 & & & & & & & & & & & & & & \\
\hline Olenidae & Peltocare Henningsmoen, 1957 & & 1 & & & & & & & & & & & & & & & & \\
\hline Pterocephaliidae & Medeselaspis Antsygin, 2001 & & 1 & & & & & & & & & & & & & & & & \\
\hline Asaphidae & Promegalaspides Westergård, 1939 & & 1 & & 1 & & & & & & & & & & & & & & \\
\hline Asaphidae & Niobe Angelin, 1851 & & 1 & & 1 & & & & & & & 1 & & & & 1 & & & \\
\hline Ceratopygidea & Macropyge Stubblefield \& Bulman, 1927 & & 1 & & 1 & & & & & & & & & & & & & & \\
\hline Remopleurididae & Apatokephalus Brøgger, 1896 & & 1 & & 1 & 1 & & 1 & 1 & 1 & 1 & & & 1 & & & & & \\
\hline Remopleurididae & Kainella Walcott, 1925 & & 1 & & & & & & & & & & & & & & & & \\
\hline Remopleurididae & Pseudokainella Harrington, 1938 & & 1 & & & & & & & & & & & & & & & & \\
\hline Hystricuridae & Hystricurus? Raymond, 1913 & & 1 & & & & & 1 & & & & & & & & & & & \\
\hline Agnostida & Leiagnostus Jaekel, 1909 & & & & 1 & & & & & & & & & & & & & & \\
\hline Agnostida & Litagnostus Rasetti, 1944 & & & & 1 & & & & & & & & & & & & & & \\
\hline Eulomidae & Euloma Angelin, 1854 & & & & 1 & & & & & & & 1 & & & 1 & & & & \\
\hline Olenidae & Saltaspis Harrington \& Leanza, 1957 & & & & 1 & & & & & & & & & & & & & & \\
\hline Olenidae & Triarthrus? Green, 1832 & & & & 1 & & & & & & & & & & & & & & \\
\hline Raymondinidae & Pseudoglaphurina Antsygin, 2001 & & & & 1 & & & & & & & 1 & & & & & & & \\
\hline Shumardiidae & Conophrys Callaway, 1877 & & & & 1 & & & & & & & & 1 & 1 & & & & & \\
\hline Shumardiidae & Hospes Stubblefield \& Bulman, 1927 & & & & 1 & & & & & & & & & & & & & & \\
\hline Triplacephalidae & Amzasskiella Poletaeva, 1960 & & & & 1 & & & & & & & & & & & & & & \\
\hline Alsataspidae & Hapalopleura Harrington \& Leanza, 1957 & & & & 1 & & & & & & & & & & & & & & \\
\hline Alsataspidae & Haplopleuroides Petrunina, 1966 nom. nudum & & & & 1 & & & & & & & & & & & & & & \\
\hline Alsataspidae & Orometopus Brøgger, 1896 & & & & 1 & & & & & & & & & & & & & & \\
\hline Alsataspidae & Pagometopus Harrington \& Leanza, 1957 & & & & 1 & & & & & & & & & & & & & & \\
\hline Asaphidae & Asaphellus Callaway, 1877 & & & & 1 & & 1 & & 1 & 1 & 1 & & & & & & & & \\
\hline Asaphidae & Birmanites Sheng, 1934 & & & & 1 & & & & & & & & & & & & & & \\
\hline Asaphidae & Megistaspis Jaanusson, 1956 & & & & 1 & & & & & & & & & & 1 & 1 & & & \\
\hline Asaphidae & Niobella Reed, 1931 & & & & 1 & & & & & 1 & 1 & & 1 & 1 & 1 & & & & \\
\hline Ceratopygidae & Ceratopyge Hawle \& Corda, 1847 & & & & 1 & 1 & & & & & & 1 & 1 & & & & & & 1 \\
\hline Cyclopygidae & Pricyclopyge Richter \& Richter, 1954 & & & & 1 & & & & 1 & & & 1 & 1 & & & & & & \\
\hline Cyclopygidae & Tyrmancyclopyge Antsygin, 2001 & & & & 1 & & & & & & & & & & & & & & \\
\hline Hungaiidae & Dikelokephalina Brogger, 1896 & & & & 1 & & & 1 & & & & & & & & & & & \\
\hline Nileidae & Nileus Dalman, 1827 & & & & 1 & & & & & & 1 & 1 & & 1 & 1 & & & & \\
\hline Nileidae & Platypeltoides Přibyl, 1949 & & & & 1 & & & & & & & & & & & & & & \\
\hline Nileidae & Varvia Tjernvik, 1956 & & & & 1 & & & & & & & 1 & & & & & & & \\
\hline Remopleurididae & Lacorsalina Burskiy, 1970 & & & & 1 & & & & & & & & & 1 & & & & & \\
\hline Remopleurididae & Richardsonella Raymond, 1924 & & & & 1 & & & & & & & & & & & & & & \\
\hline Hystricuridae & Nyaya Rozova, 1963 & & & & 1 & & & 1 & 1 & & & 1 & & & & & & & \\
\hline Hystricuridae & Tersella Petrunina, 1973 & & & & 1 & & 1 & 1 & 1 & & & & & & & & & & \\
\hline Leiostegiidae & Agerina Tjernvik, 1956 & & & & 1 & & & & 1 & & & & & & & & & & \\
\hline
\end{tabular}




\begin{tabular}{|c|c|c|c|c|c|c|c|c|c|c|c|c|c|c|c|c|c|c|c|}
\hline \multirow{2}{*}{$\begin{array}{l}\text { Trilobite families } \\
\text { \& Agnostida }\end{array}$} & & \multirow{2}{*}{$\frac{\mathrm{C}-\mathrm{O}}{1}$} & \multicolumn{2}{|c|}{$\operatorname{Tr} 1$} & \multicolumn{5}{|c|}{$\operatorname{Tr} 2$} & \multicolumn{5}{|c|}{ Tr3-F11 } & \multirow{2}{*}{$\begin{array}{c}\mathrm{F} 12-3 \\
14\end{array}$} & \multirow{2}{*}{$\begin{array}{l}\mathrm{Dp} \\
15 \\
\end{array}$} & \multicolumn{3}{|c|}{ Dw } \\
\hline & & & 2 & 3 & 4 & 5 & 6 & 7 & 8 & 9 & 10 & 11 & 12 & 13 & & & 16 & 17 & 18 \\
\hline Harpididae & Harpides Beyrich, 1846 & & & & 1 & 1 & & & & 1 & & 1 & & & & & & & \\
\hline Pilekiidae & Anacheirurus Reed, 1896 & & & & 1 & & & & & & & & & & & & & & \\
\hline Pilekiidae & Parapilekia Kobayashi, 1934 & & & & 1 & & & & & & & & & & & & & & \\
\hline Pliomeridae & Protopliomerops? Kobayashi, 1934 & & & & 1 & & & & & & & & & & & & & & \\
\hline Asaphidae & Araiocaris? Přibyl \& Vaněk 1980 & & & & & 1 & & & & & & & & 1 & 1 & 1 & & & \\
\hline Pliomeridae & Pliomeroides Harrington \& Leanza, 1957 & & & & & 1 & & 1 & 1 & 1 & 1 & 1 & 1 & & & & & & \\
\hline Asaphidae & Megalaspides Brøgger, 1886 & & & & & & 1 & & & & 1 & & & 1 & 1 & & & & \\
\hline Hungaiidae & Asaphopsoides? Hupé, 1953 & & & & & & & 1 & 1 & & & & & & & & & & \\
\hline Agnostida & Galbagnostus Whittington, 1965 & & & & & & & & 1 & & & & & & & & & & \\
\hline Agnostida & Geragnostella Kobayashi, 1939 & & & & & & & & 1 & & & & & & & & & & \\
\hline Alsataspidae & Falanaspis Tjernvik, 1956 & & & & & & & & 1 & & & & & 1 & & & & & \\
\hline Nileidae & Symphysurus Goldfuss, 1843 & & & & & & & & 1 & & & & & & & & & & \\
\hline Remopleurididae & Remopleuridiella? Ross, 1951 & & & & & & & & 1 & & & & & & & & & & \\
\hline Telephinidae & Carolinites Kobayashi, 1940 & & & & & & & & 1 & & & & & & & & & & 1 \\
\hline Encrinuridae & Cybelurus Levitskiy, 1962 & & & & & & & & & & 1 & & & & & & & 1 & \\
\hline Agnostida & Homagnostoides Kobayashi, 1939 & & & & & & & & & & & 1 & & & & & & & \\
\hline Agnostida & Machairagnostus Harrington \& Leanza, 1957 & & & & & & & & & & & 1 & & & & & & & \\
\hline Eulomidae & Bljauloma Antsygin, 2001 & & & & & & & & & & & 1 & & & & & & & \\
\hline Raymondinidae & Glaphurus Raymond, 1905 & & & & & & & & & & & 1 & & & & & & & \\
\hline Shumardiidae & Acanthopleurella Groom, 1902 & & & & & & & & & & & 1 & & & & & & & \\
\hline Hystricuridae & Batyraspis Apollonov \& Chugaeva, 1983 & & & & & & & & & & & 1 & & & & & & & \\
\hline Illaenidae & Ottenbyaspis Bruton, 1968 & & & & & & & & & & & 1 & & & & & & & \\
\hline Harpididae & Loganopeltis? Rassetti, 1943 & & & & & & & & & & & 1 & & 1 & & & & & \\
\hline Harpididae & Scotoharpes Lamont, 1948 & & & & & & & & & & & 1 & & & & & & & \\
\hline Lichidae & Lichakephalina Antsygin, 1973 & & & & & & & & & & & 1 & & & & & & & \\
\hline Cheiruridae & $\begin{array}{l}\text { Bornholmaspis? Přibyl \& Vaněk in Přibyl et al., } \\
1985\end{array}$ & & & & & & & & & & & 1 & & & & & & & \\
\hline Raphiophoridae & Lonchodomas Angelin, 1854 & & & & & & & & & & & & & 1 & 1 & & & & 1 \\
\hline Styginidae & Raymondaspis Přibyl, 1949 & & & & & & & & & & & & & 1 & & & & & \\
\hline Raphiophoridae & Amyxella? Dean, 1960 & & & & & & & & & & & & & & 1 & & & & \\
\hline Remopleurididae & Eorobergia Cooper, 1953 & & & & & & & & & & & & & & 1 & & & & \\
\hline Asaphidae & Asaphus? Brongniart, 1822 & & & & & & & & & & & & & & & 1 & & & 1 \\
\hline Asaphidae & Megistaspis (Megistaspidella) Jaanusson, 1956 & & & & & & & & & & & & & & & 1 & & & \\
\hline Cheiruridae & Cyrtometopus Angelin, 1854 & & & & & & & & & & & & & & & & 1 & 1 & \\
\hline Encrinuridae & Cybele Loven, 1845 & & & & & & & & & & & & & & & & 1 & & \\
\hline Pterygometopidae & Pterygometopus Schmidt, 1881 & & & & & & & & & & & & & & & & 1 & & \\
\hline Isocolidae & Cyphoniscus Salter, 1853 & & & & & & & & & & & & & & & & & 1 & \\
\hline Isocolidae & Holdenia Cooper, 1953 & & & & & & & & & & & & & & & & & 1 & \\
\hline Isocolidae & Pseudopetigurus Prantl \& Přibyl, 1949 & & & & & & & & & & & & & & & & & 1 & \\
\hline Raymondinidae & Glaphurina Ulrich, 1930 & & & & & & & & & & & & & & & & & 1 & \\
\hline Remopleurididae & Remopleurides Portlock, 1843 & & & & & & & & & & & & & & & & & 1 & 1 \\
\hline Holotrachelidae & Kinderlania Antsygin, 1977 & & & & & & & & & & & & & & & & & 1 & \\
\hline Telephinidae & Phorocephala? Lu in Lu et al., 1965 & & & & & & & & & & & & & & & & & 1 & \\
\hline Illaenidae & Illaenus Dalman, 1827 & & & & & & & & & & & & & & & & & 1 & \\
\hline Illaenidae & Platillaenus Jaanusson, 1954 & & & & & & & & & & & & & & & & & 1 & \\
\hline Lichidae & Metopolichas Gürich, 1901 & & & & & & & & & & & & & & & & & 1 & \\
\hline Lichidae & Platylichas Gürich, 1901 & & & & & & & & & & & & & & & & & 1 & \\
\hline Odontopleuridae & Ceratocephala Warder, 1838 & & & & & & & & & & & & & & & & & 1 & \\
\hline Cheiruridae & Heliomera Raymond, 1905 & & & & & & & & & & & & & & & & & 1 & \\
\hline Cheiruridae & Kawina Barton, 1916 & & & & & & & & & & & & & & & & & 1 & \\
\hline Cheiruridae & $\begin{array}{l}\text { Pateraspis Přibyl \& Vaněk in Přibyl et al., } \\
1985\end{array}$ & & & & & & & & & & & & & & & & & 1 & \\
\hline Pliomeridae & Pliomera Angelin, 1854 & & & & & & & & & & & & & & & & & 1 & 1 \\
\hline Asaphidae & Plectasaphus Jaanusson, 1953 & & & & & & & & & & & & & & & & & & 1 \\
\hline Cheiruridae & Ceraurinella Cooper, 1953 & & & & & & & & & & & & & & & & & & 1 \\
\hline Pterygometopidae & Calyptaulax Cooper, 1930 & & & & & & & & & & & & & & & & & & 1 \\
\hline & Number of taxa & 4 & 19 & 3 & 42 & 5 & 3 & 8 & 15 & 5 & 8 & 22 & 6 & 12 & 9 & 5 & 3 & 19 & 9 \\
\hline
\end{tabular}




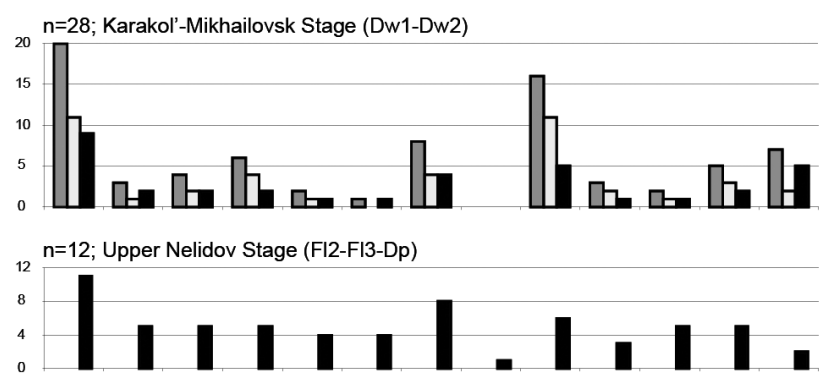

25 n=33; Kuagach Stage; Lower Nelidov Stage (Tr3-FI1)

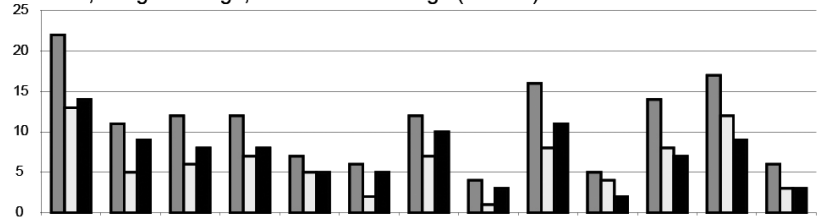

$\mathrm{n}=53$; Kolnabuk Stage; Sokoli Stage $(\mathrm{Tr} 2)$

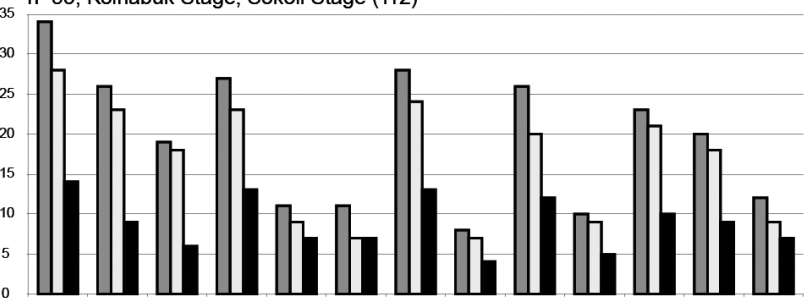

$n=19 ;$ Kidryas Stage (Tr1)

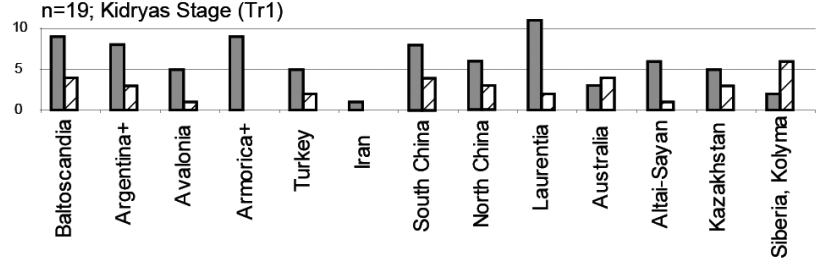

D no of genera of Cambrian origin

WI genera of Ordovician origin: all over Urals and Pay-Khoy; South only; North only

Figure 5. Palaeogeographic distribution of the Tremadocian-Darriwilian genera found in the Uralian side of Baltica (for the intervals and data see Fig. 2, Table 1B)

the South Urals (Antsygin 1977, Korinevskiy 1989) were attributed to the genus Jdyia (Antsygin 2001) but without any comment. It is not clear whether this genus alone occurs in the South Urals to the exclusion of Nyaya and Tersella. A problematic taxon Hystricurus conicus (Billings, 1859) figured by Balashova (1961, pl. 1, figs 12-14) may also belong to Jdyia. Burskiy's (1970) taxa from Pay-Khoy (Nyaya novozemelica Burskiy, 1970; N. paichoica Burskiy, 1970; N. sokoliensis Burskiy, 1970; Tersella? magnaoculus Burskiy, 1970) are figured without description and we agree with Adrain \& Westrop (2006) that they are nomina nuda. The latter authors discussed the systematic position of Nyaya and Tersella and considered them more similar to the hystricurids (as suggested already by Rozova 1968, and Antsygin 2001) than to the aphelaspidines (see Shergold 1982, Jago 1987, Shergold et al. 2000). In general, the hystricurids tend to have a fairly small and crescentic palpebral lobe and highly vaulted gla- bella, while Tersella, Nyaya and Jdyia have a flat glabella, and a larger, sausage-shaped palpebral lobe that is closer to the glabella and separated by a deep furrow from the fixigena. These characters are fairly stable within families, and they are therefore clearly different from any hystricurid. The major difference between the hystricurids and Jdyia-Tersella-Nyaya group is that the former has a median preglabellar depression causing the glabella to appear more pointed medially. In the Jdyia-Tersella-Nyaya group the preglabellar area is inflated and the glabella is trapezoidal anteriorly. Still, the Jdyia-Tersella-Nyaya group is very similar to some of the latest Cambrian aphelaspidine genera from the outer shelf of the Siberia such as Nganasanella Rozova, 1963, Olentella Ivshin, 1956, Amorphella Rozova, 1963, and Monosulcatina Rozova, 1963 (Rozova 1968, pls 7-9; Pegel 2000, fig. 9). They also resemble the Cambrian parabolinoidid Taenicephalops Ergaliev, 1980, which possibly includes Aphelaspis? kazachstanica Lisogor, 1977, both known from Maly Karatau, Kazakhstan (Ergaliev 1980). The Lower Tremadocian Lusampa Petrunina, 1990 from the northeastern Salair, Altai-Sayan region is rather variable. Of the three species listed, Lusampa tenuis Petrunina, 1990 is very similar to N. paichoica Burskiy, 1970 nom. nudum, while Lusampa interposita Petrunina, 1990 resembles Jdyia, and leaves the type species Lusampa cupoides Petrunina, 1990 sufficiently different. Unfortunately, it is difficult to judge the similarity by the photographs. However, all these Cambrian genera possess smaller palpebral lobe than the Uralian group. In that character the latter resembles a hystricurid Millardicurus Adrain \& Westrop, 2006, and we include these genera tentatively within the hystricurids in our data set (Fig. 4).

Several widely distributed Tremadocian genera, such as Dikelokephalina, Ceratopyge and Amzasskiella first appear within the Kolnabuk Stage in the Urals. Ebbestad (1999) recently revised the type material of Ceratopyge and lists its occurrence as being Baltica, China, Argentina and Kazakhstan. The latter, a record from Balashova (1961) actually represents the Aktyube region of South Urals. In addition, Ceratopyge has been known from Armorica (Hammann et al. 2008), and Perunica (Mergl 2006), and from Altai-Sayan (Fig. 3; Petrunina 1960, 1990). In the Urals Ceratopyge occurs from the Kolnabuk to Kuagach stages in South and Polar Urals. More problematic is the record from Pay-Khoy. Some of the specimens ascribed to Ceratopyge, e.g. two cranidia figured by Burskiy (1970, pl. 6, figs 10, 15) are better to assign to Agerina. These resemble most Agerina ferrigena (Růžička, 1926) from the upper Tremadocian Třenice Formation in Bohemia (Mergl 2006, text-fig. 14), and Agerina praematura (Tjernvik, 1956) from the Bjørkåsholmen Formation in Baltoscandia. Otherwise Agerina is recorded from the southern Urals (Popov \& Holmer 1994). 
This genus may have been derived from the Lower Tremadocian Brackenbuschia Harrington \& Leanza, 1957 of Argentina (for discussion see Adrain \& Fortey 1997, Sdzuy et al. 2001, Mergl 2006). Thus during the Tremadocian times Agerina and associates mainly lived in the West Gondwana but extended to both sides of Baltica.

Dikelokephalina was common in the Tremadocian of the Urals and contemporaneously worldwide (for discussion on systematics and distribution see Fortey 2010). Specimens reached a large size in the Morocco region (Fortey 2009, 2010) at high latitudes of West Gondwana. Gigantism is more pronounced for Darriwilian trilobites in the Valongo region of the Armorica terrane also located at high latitudes (Gutiérrez-Marco et al. 2009). In Baltoscandia the largest trilobites are the Kundan (Darriwilian) asaphids (Pärnaste et al. 2013), a group of similar morphology and possibly of similar life style (Pärnaste \& Bergström 2013). To date no large dikelokephalids or asaphids have been recorded from the Uralian side of Baltica even though the palaeolatitude is similar.

Amzasskiella, a peculiar trilobite genus with a bulb in front of the glabella possibly developed as a brood pouch (Fortey \& Hughes 1998), has been recorded in many regions, mainly from assumed warm climate areas of East Gondwana, Siberia, Altai-Sayan, and Kazakhstan. However, the early Tremadocian representatives appear in Cordillera Oriental and Western Puna (Vaccari \& Waisfeld 2008) in temperate climates at similar latitudes to Baltica (e.g. Monti \& Confalonieri 2013). The Uralian species of Kolnabuk age may have arrived from both areas.

Saltaspis is restricted to the South America and Baltica. The earliest occurrences are from the Lower Tremadocian Olenid fauna of the Cordillera Oriental and southern Bolivia (Přibyl \& Vaněk 1980, Waisfeld \& Vaccari 2003), and from the Digermul Peninsula of Finnmark, northern Norway (Nikolaisen \& Henningsmoen 1985). The distribution of Saltaspis extends towards higher latitudes by the Middle Tremadocian involving southern part of the Baltoscandian Palaeobasin and South Urals.

Thirty-four Kolnabukian genera are shared with Baltoscandia and only two (Tyrmancyclopyge and Alimbetaspis) are endemic. Of the new arrivals two thirds are of Cambrian origin. The largest number of these genera is shared with South China (7), Kazakhstan (6) and Argentina (5). When comparing the faunas of the Ordovician origin, the greatest similarity is with faunas of Baltoscandia, reaching $65 \%$, and nearly half of the Uralian genera are shared with South China, Armorica, Argentina and Laurentia terranes. Slightly less than $40 \%$ of the Kolnabukian genera occur in the Altai-Sayan, Kazakhstan and Avalonia, while only a fifth occur in other terranes (Fig. 5, Table 1B). All together, the Kolnabukian fauna shows high rate of globalization.

\section{Kuagach and Nelidov Regional Stages}

The Kuagachian fauna is of latest Tremadocian and earliest Floian age (Figs 2, 4). The number of genera is reduced to thirty-three. Otherwise there is little change compared to the preceding fauna, except the new addition of the Lichida. The family Olenidae within Ptychopariida disappears. Thus the ptychopariids decrease by half, leaving more space for corynexochids and harpetids. This replacement possibly reflects shallower shelf conditions and also the Ceratopyge Regressive Event well recorded on the Baltoscandian side of the Baltica (Ebbestad 1999). In numbers, the most abundant species of the Kuagachian fauna belong to the genera Ottenbyaspis, Pricyclopyge, Nileus and Ceratopyge. By this time, as in the previous interval, a differentiation between the development of faunas in north and south can be detected. In Pay-Khoy two thirds of the recorded genera belong to the Asaphida, while in the Sakmara Zone the figure is only about one quarter. In addition to the Asaphida seven other trilobite orders are represented. The ptychopariids disappear, except for Shumardia (Fig. 4, Table 1A).

In comparison with other areas where Uralian genera occur, there is a change towards sharing proportionately more genera with Baltoscandia, and fewer with the North China Plate and Laurentia. Also fewer genera connect the Urals with the Kazakh, Altai-Sayan and Iran terranes at the time (Fig. 5, Table 1B).

The Late Floian-Dapingian deposits are less known on the Uralian side of Baltica and the trilobite fauna is recorded only from the upper part of the Nelidov Regional Stage in Pay-Khoy hills on Yugorsky Peninsula at the northern tip of the Urals. The two beds included here are the Phyllograptus aff. densus \& Eorobergia nericensis bed, and the Megistaspis limbata \& Trigonograptus ensiformis Bed, containing mainly asaphids (Niobe, Niobella, Megistaspis, Megalaspides), plus remopleuridids (Apatokephalus, Lacorsalina, Eorobergia), Euloma and Raymondaspis (Fig. 4). A fauna from Pay-Khoy shares all genera with Baltoscandia except for the remopleuridid, Lacorsalina, which is shared with Spitsbergen, where it occurs in the younger beds (Fortey 1980). The asaphids are clearly dominant in number of species, followed by remopleuridids.

\section{Karakol'-Mikhailovsk Regional Stage}

The Darriwilian Karakol-Mikhailovsk Stage contains a diverse trilobite fauna (Fig. 4, Table 1A) but the difference in faunal content between the north and south Urals becomes greater. Families making their first appearance in the region are Pterygometopidae and Odontopleuridae. All nine genera from the Sub-Polar and Polar Urals in the north (i.e. Asaphus, Lonchodomas, Remopleurides, Pliomera, 
Table 1B. List of the trilobite genera of the Uralian border of Baltica (Weber 1948; Bondarev et al. 1965; Burskiy 1966, 1970; Varganov et al. 1973; Antsygin 1977, 1978, 1991, 1993, 2001; Antsygin et al. 1977; Klyuzhina 1985; Puchkov 1991; Bergström et al. 2013) shown with distribution on the other terranes. Main references to the faunas reviewed from different areas are as follows: Baltoscandia (Tjernvik 1956; Henningsmoen 1957; Ebbestad 1999; Żylińska 2002; Terfelt et al. 2011; Pärnaste et al. 2009, 2013), Argentina plus Bolivia (Robison \& Pantoja-Alor 1968; Přibyl \& Vaněk 1980; Waisfeld \& Vaccari 2003; Tortello \& Esteban 2007; Balseiro \& Marengo 2008; Vaccari \& Waisfeld 2008), Avalonia (Owens et al. 1982; Fortey \& Owens 1991), Armorica: Iberia (Álvaro et al. 2007, Hammann et al. 2008), Montagne Noir (Vizcaïno et al. 2001, Vizcaïno \& Álvaro 2003, Shergold et al. 2007), Bavaria (Sdzuy et al. 2001), Perunica (Mergl 2006), Turkey (Shergold \& Sdzuy 1984, Dean 2006), Alborz, Iran (Ghobadi Pour 2006, Ghobadi Pour et al. 2007, Bruton et al. 2004), South China (Lu 1975; Peng 1990a, 1990b, 1992; Zhou \& Zhen 2008; Zhou et al. 2011), North China (Kuo et al. 1982, Sohn \& Choi 2002), Australia (Jell 1985, Jell \& Stait 1985, Shergold et al. 2007), Laurentia including Western Ireland, Scotland (Ludvigsen 1982, Pratt 1988, Adrain \& Fortey 1997, Fortey \& Droser 1999), Siberia (Rozova 1968, 1977, 1984; Ogienko 1974, 1984; Timokhin 1989; Pegel 2000; Lazarenko \& Pegel 2001; Lazarenko et al. 2011), Kolyma (Chugaeva 1973), and Kazakhstan: Kokchetav - Middle Tianshan Microcontinent (Ulutau-Karatau-Naryn) (Lisogor 1977a, 1977b; Ergaliev 1980, 1983; Apollonov \& Chugaeva 1983), Stepnayk - Northern Tianshan Microcontinent (Kendyktas Range) (Lisogor 1961, Popov \& Holmer 1994), Zheltau and Atasu-Junggar volcanic arcs (Chu-Ili) (Chugaeva 1958), Baydaulet-Akbastau arc (Olenty River and Dzhungaria) (Ivshin 1956, 1962; Popov \& Holmer 1994), Altai-Sayan (Kuznetsk-Alatau, Gornaya Shoria, Salair, Gorny Altai) (Sivov 1955; Petrunina 1960, 1990; Poletaeva 1960, 1977; Rozova 1960; Rozova et al. 1985).

\begin{tabular}{|c|c|c|c|c|c|c|c|c|c|c|c|c|c|c|c|c|c|c|c|c|c|c|c|c|}
\hline \multirow[b]{2}{*}{ Other regions / terranes } & \multicolumn{11}{|c|}{ Cambrian } & \multicolumn{13}{|c|}{ Ordovician } \\
\hline & 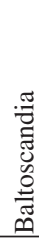 & 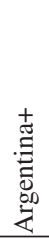 & $\frac{\stackrel{\pi}{3}}{\frac{0}{\pi}}$ & 离 & 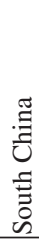 & 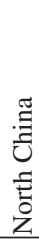 & 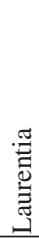 & 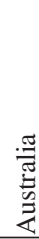 & 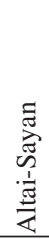 & 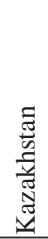 & 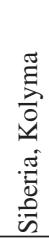 & 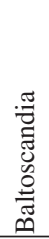 & 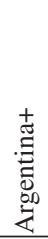 & $\frac{\pi}{\frac{\pi}{3}}$ & 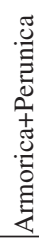 & $\underset{\vec{\partial}}{\stackrel{\vec{y}}{\Xi}}$ & $\underset{\mathbb{T}}{\mathbb{E}}$ & 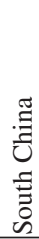 & 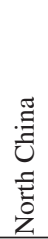 & 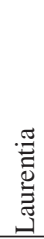 & 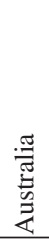 & 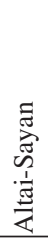 & 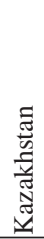 & 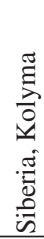 \\
\hline Acanthopleurella Groom, 1902 & & & & & & & & & 1 & & & & & 1 & & & & & & & & 1 & & \\
\hline Acerocarina Poulsen, 1952 & 1 & & & & & & & & & & & 1 & 1 & & & & & & & & & & & \\
\hline Agerina Tjernvik, 1956 & & & & & & & & & & & & 1 & 1 & & 1 & 1 & & 1 & & 1 & & & & \\
\hline $\begin{array}{l}\text { Akoldinioidia Zhou \& Zhang, } 1984 \\
\text { Alimbetaspis Balashova, } 1961\end{array}$ & & & & & 1 & 1 & & 1 & & & & & 1 & & & 1 & & & & & & & & \\
\hline Amzasskiella Poletaeva, 1960 & & 1 & & & & & & & & & & & 1 & & & & & 1 & 1 & & 1 & 1 & 1 & 1 \\
\hline Amyxella? Dean, 1960 & & & & & & & & & & & & 1 & & 1 & & & & 1 & & & & & & \\
\hline Anacheirurus Reed, 1896 & & & & & & & & & & & & & & 1 & 1 & & & & & & & 1 & & \\
\hline Apatokephalus Brøgger, 1896 & & & & & & & & & 1 & & 1 & 1 & 1 & 1 & 1 & 1 & 1 & 1 & 1 & 1 & & 1 & 1 & 1 \\
\hline Araiocaris? Přibyl \& Vaněk, 1980 & & & & & & & & & & & & & 1 & & & & & & & & & & & \\
\hline Asaphellus Callaway, 1877 & & 1 & & & 1 & & & 1 & & & & & 1 & 1 & 1 & & 1 & 1 & 1 & 1 & & 1 & 1 & \\
\hline Asaphopsoides? Hupé, 1953 & & & & & & & & & & & & & & & 1 & & 1 & & & & & & & \\
\hline Asaphus? Brongniart, 1822 & & & & & & & & & & & & 1 & & & & & & & & & & & & \\
\hline Batyraspis Apollonov \& Chugaeva, 1983 & & & & & & & & & & & & & & & & & & & & & & & 1 & \\
\hline Birmanites Sheng, 1934 & & & & & & & & & & & & & 1 & & 1 & & & 1 & & 1 & & & & \\
\hline Bljauloma Antsygin, 2001 & & & & & & & & & & & & & & & & & & & & & & & & \\
\hline $\begin{array}{l}\text { Bornholmaspis? Přibyl \& Vaněk in Přibyl et al., } \\
1985\end{array}$ & & & & & & & & & & & & 1 & & 1 & & & & & & & & & & \\
\hline Calyptaulax Cooper, 1930 & & & & & & & & & & & & 1 & & 1 & & & & 1 & & 1 & & & & \\
\hline Carolinites Kobayashi, 1940 & & & & & & & & & & & & 1 & & & & 1 & 1 & & & 1 & & & & 1 \\
\hline Ceratocephala Warder, 1838 & & & & & & & & & & & & 1 & & & & & & & & 1 & & & & \\
\hline Ceratopyge Hawle \& Corda, 1847 & & & & & & & & & & & & 1 & 1 & & 1 & & & 1 & & & & 1 & & \\
\hline Ceraurinella Cooper, 1953 & & & & & & & & & & & & 1 & & & & & & & & 1 & & & & 1 \\
\hline Conophrys Callaway, 1877 & & 1 & & & 1 & 1 & & & & 1 & & 1 & 1 & 1 & 1 & & 1 & 1 & 1 & 1 & & 1 & 1 & 1 \\
\hline Cybele Loven, 1845 & & & & & & & & & & & & 1 & & & & & & & & & & & & \\
\hline Cybelurus Levitskiy, 1962 & & & & & & & & & & & & 1 & & 1 & & & & & & 1 & & 1 & & \\
\hline Cyphoniscus Salter, 1853 & & & & & & & & & & & & & & 1 & & & & & & 1 & & & & \\
\hline Cyrtometopus Angelin, 1854 & & & & & & & & & & & & 1 & & & & & & & & & & & & \\
\hline Dikelokephalina Brøgger, 1896 & & & & & & & & & & & & 1 & & 1 & 1 & & 1 & 1 & 1 & & 1 & 1 & 1 & 1 \\
\hline Dolgedola Antsygin, 2001 & & & & & & & & & & & & & & & & & & & & & & & & \\
\hline Eorobergia Cooper, 1953 & & & & & & & & & & & & 1 & & & & & & & & 1 & & 1 & & \\
\hline Euloma Angelin, 1854 & & & & & 1 & & & & & & & 1 & & 1 & 1 & 1 & 1 & 1 & & 1 & & 1 & 1 & 1 \\
\hline Falanaspis Tjernvik, 1956 & & & & & & & & & & & & 1 & & & & & & & & 1 & & & & \\
\hline Galbagnostus Whittington, 1965 & & & & & & & & & & & & & & 1 & & & & & & 1 & & & & \\
\hline Geragnostella Kobayashi, 1939 & & & & & & & & & & & & & & & 1 & & & 1 & & & & & & \\
\hline Geragnostus Howell, 1935 & & & & & & & & & & & & 1 & & & 1 & 1 & & 1 & & 1 & & & 1 & \\
\hline Glaphurina Ulrich, 1930 & & & & & & & & & & & & 1 & & & & & & & & 1 & & & 1 & \\
\hline Glaphurus Raymond, 1905 & & & & & & & & & & & & & & & & & & & & 1 & & 1 & & 1 \\
\hline Hapalopleura Harrington \& Leanza, 1957 & & 1 & & & & & & & & & & & 1 & & & & & & & & & & & \\
\hline Haplopleuroides Petrunina, 1966 nom. nudum & & & & & & & & & & & & & & & & & & & & & & & & \\
\hline Harpides Beyrich, 1846 & & & & 1 & & & & & & 1 & & 1 & 1 & & 1 & & & 1 & & 1 & 1 & 1 & 1 & \\
\hline Heliomera Raymond, 1905 & & & & & & & & & & & & & & & & & & & & 1 & & & & \\
\hline Holdenia Cooper, 1953 & & & & & & & & & & & & & & & 1 & & & & & & & & & \\
\hline Homagnostoides Kobayashi, 1939 & & & & & & & & & & & & & & & 1 & & & & & & & & 1 & \\
\hline Hospes Stubblefield \& Bulman. 1927 & & 1 & & & 1 & & & & & 1 & & 1 & 1 & 1 & & & & 1 & & & & & 1 & \\
\hline
\end{tabular}




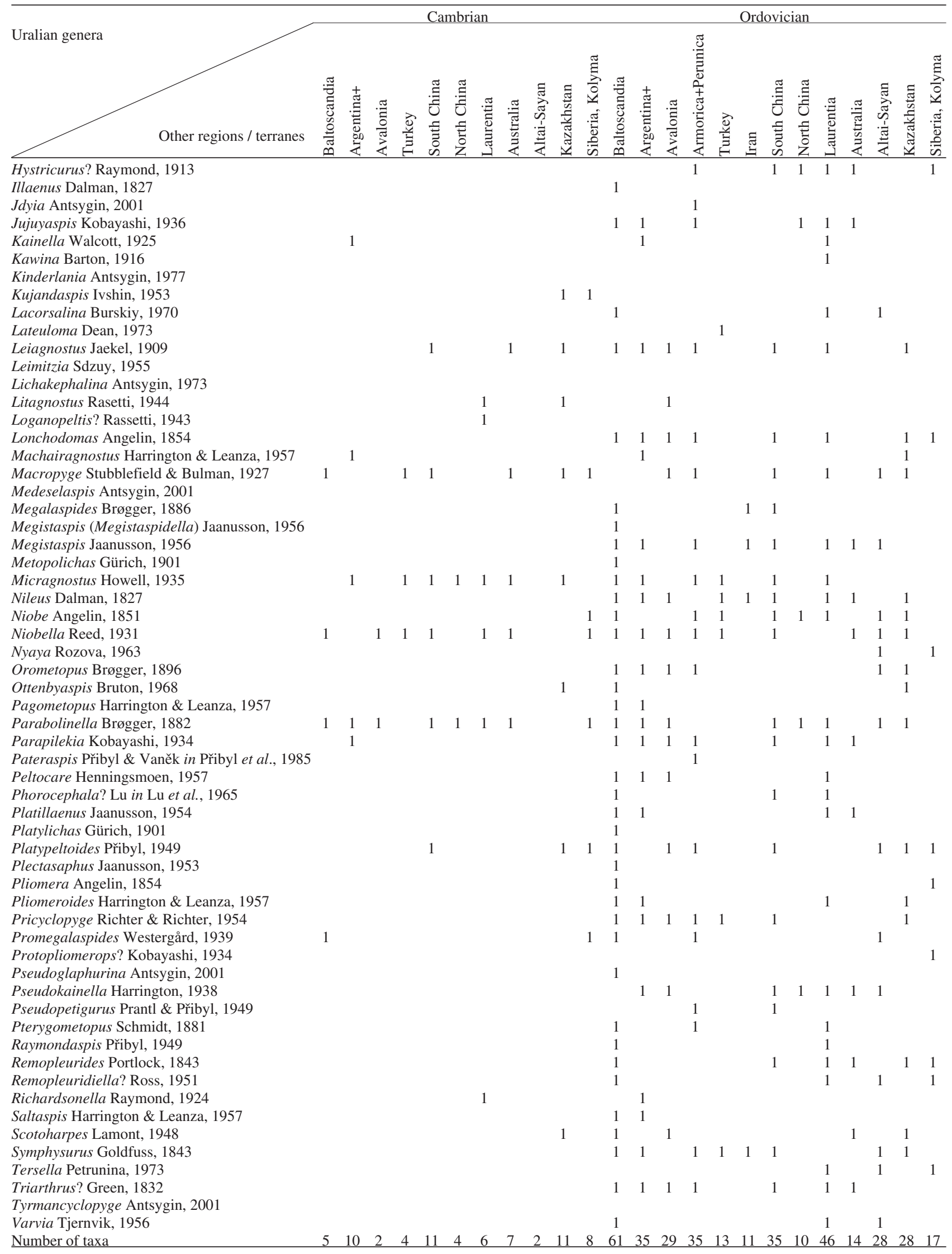


Cyrtometopus, Illaenus, Platillaenus, Metopolichas, and Platylichas) occur also in Baltoscandia, but of twenty-one genera in the south, ten are absent in Baltoscandia (Table 1B). This is the case with the holotrachelid Kinderlania, which is endemic to the Urals, the three isocolids: Holdenia, Pseudopetigurus, and Cyphoniscus with an origin in Armorica, Perunica and Avalonia respectively, and a cheirurid Pateraspis that is common in Armorica and Perunica. The two other cheirurids Kawina and Heliomera are found on the Iapetus-side of Laurentia, including western Newfoundland and Spitsbergen. There is thus a clear faunal separation between south and north in the Early Darriwilian, with no connection at the species level (Bergström et al. 2013). The only exception is Pliomera fisheri (Eichwald, 1825) a broadly defined species in need of revision. This taxon contains a group in which the anterior-most glabellar furrows terminate in the anterior border furrow instead of the axial furrow and the anterior border is denticulated to receive the pygidial spines during enrolment (see Öpik 1937, pl. 19, fig. 4; Schmidt 1881, pl. 13, figs 1-4). Pliomera fisheri asiatica (Chugaeva, 1973) from Kolyma has reduced lateral lobes similar to those on specimens from the Urals (Antsygin 1977, pl. 5, figs 7-8; 1991, pl. 25, figs 1-3) and to those from the allochthonous Otta serpentine conglomerate of Norway, which possibly represents an intra-Iapetus island located somewhere between Baltica and Laurentia in Darriwilian times (Bruton \& Harper 1981, Harper et al. 2009). Pliomera first appears in the Dapingian and early Darriwilian of Baltoscandia (Pärnaste et al. 2013), where it is often associated with the mud mounds that might signal the occurrences of similar environments for the accumulation of such formations in the Urals, as well as in Kolyma. Pliomera is also reported from the lower Darriwilian Kunda Stage of the Moscow Basin (Dmitrovskaya 1989, Bergström et al. 2013), which may indicate a direct pathway of these faunas via that basin.

The separation of the Karakol-Mikhailovskian faunas is also characterised by a major difference in diversity and in dominant groups (Fig. 4). The trilobite assemblage from the Polar and Sub-Polar Urals is strongly dominated by asaphids that agree well with Baltoscandian Asaphid fauna, while in the south Urals there occurs a reef-related cheirurid facies fauna comparable to that known from Laurentia (see e.g. Whittington 1963, 1965; Ross 1972; Fortey 1980). Besides, of these cheirurid and raymondinid genera, connecting the Uralian fauna with the Laurentian, only a very few are common to the other regions (Fig. 5, Table 1B). This condition does not fit with the pattern of the palaeogeographical maps for the Mid-Darriwilian (Dw2). However, conodont distributions show a similar influx of the North American faunas at this level (e.g. Nasedkina 1981, Dubinina \& Ryazantsev 2008). The most probable interpretation is that we are dealing with deep-water conditions, known to conodont specialists as the Tropical
Domain of the Open-Sea Realm (Zhen \& Percival 2003, Dubinina \& Ryazantsev 2008). The South Urals is thus distinguished from the rest of Baltica by having a Laurentian fauna equivalent to that conodont fauna. An explanation for this is difficult in terms of available palaeogeographical reconstructions (e.g., Cocks \& Fortey 1998, Torsvik \& Andersen 2002, Cocks \& Torsvik 2005, Harper et al. 2009). Perhaps a similar marginal fauna existed northwest of present-day Norway, but the proof is missing, because much of the Baltic crust was subducted (Cocks \& Fortey 1998). Or perhaps the allochtonous belts of the Oslo region formed links between Baltica and Spitsbergen or other regions related to Laurentia earlier than in Late Ordovician as referred by Bergström et al. (2010).

\section{Summary}

All together 96 genera of trilobites and 8 genera of agnostid arthropods are recorded from the Uralian side of Baltica from the Tremadocian to the middle Darriwilian (= Ölandian of Baltoscandia). This number is about one fifth fewer than recorded from the Baltoscandian side (Pärnaste et al. 2013) though figures from the east are based on a fewer studies and localities.

Summarizing the evolution of faunas, it can be noted that the lower Tremadocian in the south contains a fairly rich fauna with some 16 genera, plus 3 agnostoids. Half of this fauna belongs to genera of Cambrian origin, including the olenids and the earliest asaphids and ceratopygids. The later Tremadocian, both in the north and the south, includes the Ceratopyge Biofacies, with much variation in composition and richer than earlier. The post-Tremadocian development involved a wider divergence between north and south. In the north there was a strong diversification of asaphids. Although the Asaphid Biofacies is recognisable, it is notably different and much poorer than that of Baltoscandia. Thus the upper Floian and Dapingian levels contain some ten asaphids in north. The lower Darriwilian is dominated by cheiruroids in south and only a few asaphids, indicating connections with Baltoscandia. In the North Urals, however, the taxonomic composition resembles that in Baltoscandia.

The richness of faunas in different terranes depends on the timing, extension and variability of the sedimentary environment, preservation of the rock and range of the areas (compare South China with Alborz), which in turn influences the number of shared taxa. Thus terranes with the highest number of shared taxa may reflect the existence of linking pathways for so called pandemic taxa rather than a close proximity of these terranes. In the late Cambrian and early Tremadocian, terranes lined up as a border of Gondwana with Baltica, made possible the connection farther north towards Siberia and other low latitude terranes and 
may have favoured the global distribution of numerous trilobite genera.

Of all genera known from the Early to early Middle Ordovician of the Urals three-fifths are present also in Baltoscandia, and only eight genera are endemic to the Urals. About half of the genera recorded there occur also in Laurentia, and about one-third are known in South China, Argentina, Avalonia, Armorica (together with Iberia and Perunica), Altai-Sayan and Kazakh terranes. Fewer genera are shared with Siberia, North China, Australia, and with the smaller terranes of Turkey and Iran. Thus, approximately one-third of the Uralian trilobite fauna consists of cosmopolitan elements. A different aspect is revealed when comparing fauna of the Cambrian origin - the closest match is with Siberia and Kazakhstan. Obviously, there is a big change in the palaeogeographical situation between the Furongian and the early Ordovician when the Siberian Palaeoplate drifted away from Baltica and restricted the exchange of faunas.

In the case of shared exotic taxa this may be explained by the existence of continuous migration routes related to relatively close proximity of terranes or by special oceanic currents. Thus on the Uralian side of Baltica the occurrence of Kujandaspis in Khmelevian beds shows evidence of migration of the Cambrian fauna with Siberia and Kazakhstan and Promegalaspides with the Baltoscandian side. In both cases the Pechora Basin as a pathway is one possible option. Elsewhere the hungaiid, Leimitzia, indicates a migration between the Urals and Bavaria with the Perunica terrane positioned at high latitudes during Kidryasian times and way south of Baltica. Other examples include the co-occurrence of the Uralian isocolids Holdenia, Pseudopetigurus, and Cyphoniscus in Armorica, Perunica and Avalonia respectively, and the cheirurid Pateraspis in Armorica and Perunica. Extraordinarily, the two other cheirurids Kawina and Heliomera, occur from the Urals as far as to the Iapetus-side of Laurentia in the Darriwilian reefs of Nevada, western Newfoundland and Spitsbergen, marking a pathway of migration.

In summary, the gradual decrease of the number of genera shared between the Urals and other parts of the world shows decrease of pandemism during the Early Ordovician. The loss of the Olenid fauna first, and then the Ceratopyge fauna to be replaced by the Asaphid fauna, which later becomes almost endemic to Baltica and is joined by a few exotic immigrants from East Gondwana and Laurentia in the early Middle Ordovician. This gradual endemism coincides with an eventual separation of the Uralian side of Baltica from neighbouring terranes.

\section{Acknowledgements}

This paper is just one of research in a two year period of collaboration before Jan Bergström's unfortunate death in No- vember 2012. The results were presented at the $5^{\text {th }}$ Conference on Trilobites and their relatives held in Prague, Czech Republic in July 2012. The project is supported by the Estonian Science Grant No. 8054, the Estonian Ministry of Education and Research Project SF0140020s08, and by the Palaeozoology Department of the Swedish Museum of Natural History. The present study is a contribution to the International Geoscience Programme project 591 "The Early to Middle Paleozoic Revolution". HP is grateful to the reviewers David L. Bruton (Natural History Museum, University of Oslo) and Robert M. Owens (National Museum of Wales, Cardiff) for their kind help on improving language, and special thanks go to Nikolay Y. Antsygin (The Ural State Mining University, Yekaterinburg) who friendly supplied his monograph immediately after the request.

\section{References}

AdRAin, J.M. \& ForTey, R.A. 1997. Ordovician Trilobites from the Tourmakeady Limestone, Western Ireland. Bulletin of the Natural History Museum of London, Geology Series 53, $79-115$.

AdRain, J.M. \& WeStrop, S.R. 2006. New earliest Ordovician trilobite genus Millardicurus: the oldest known hystricurid. Journal of Paleontology 80(4), 650-671.

DOI 10.1666/0022-3360(2006)80[650:NEOTGM]2.0.CO;2

Álvaro, J.J., Ferretti, A., GonzÁlez-Gómez, C., Serpagli, E., Tortello, M.F., Vecoli, M. \& Vizcaïno, D. 2007. A review of the Late Cambrian (Furongian) palaeogeography in the western Mediterranean region, NW Gondwana. Earth-Science Reviews 85, 47-81. DOI 10.1016/j.earscirev.2007.06.006

Angelin, N.P. 1851. Palaeontologia Svecica. I: Iconographia crustaceorum formationis transitionis. Fasciculi 1, 1-24. Weigel, Lund.

Angelin, N.P. 1854. Palaeontologia Scandinavica. I: Crustacea formationis transitionis. Fasciculi 2, 21-92. Leipzig, Lund.

AnTSYgin, N.Y. 1973. Trilobites, 62-111. In Varganov, V.G., Antsygin, N.Y., NASEdkina, V.A., Militsina, V.S. \& ShuRyGINA, M.V. (eds) Stratigraphy and faunas of the Ordovician of the Middle Urals. Nedra, Moscow. [in Russian]

AnTSYgin, N.Y. 1977. Trilobites of the Karakol'-Mikhailovsk horizon of the Lower Ordovician of the southern Urals, 68-95. In Sapel'nikov, V.P. \& Chuvashov, B.I. (eds) Palaeontological information of the Middle Palaeozoic of Ural and Sibiria. Akademiya nauk SSSR, Uralskiy nauchnyi tsentr, Trudy Instituta geologii i geokhimii 126. [in Russian]

Antsygin, N.Y. 1978. The lower Ordovician trilobites of the Mayachnaya Gora in Bredin region. Akademiya nauk SSSR, Trudy Instituta geologii i geokhimii 135, 30-44. [in Russian] Antsygin, N.Y. 1991. Trilobites, 105-125. In Puchkov, V.N. (ed.) Ordovician of Sub-Polar Urals. Palaeontology. UrO AN SSSR, Sverdlovsk. [in Russian]

Antsygin, N.Y. 1993. Trilobites, 34-46. In Antsygin, N.Y., Popov, B.A. \& Chuvashov, P. (eds) Stratigraphic Charts of the Urals Region. Institute of Geology and Geochemistry, Russian Academy of Sciences, Roskomnedra, Ekaterinburg. [in Russian] 
Antsygin, N.Y. 2001. Tremadocian trilobites of the Urals. 247 pp. OAO Uralskaya geologosemochnaya ekspeditsiya, Ekaterinburg. [in Russian]

Antsygin, N.Y., Nasedkina, V.A. \& Rozov, S.H. 1977. Cambrian-Ordovician boundary beds at the left side of Medes River, 184-197. In ZhuRAvleva, I.T. \& Rozova, A.V. (eds) Biostratigraphy and fauna of the Upper Cambrian and the boundary strata (New data from the Asiatic part of the U.S.S.R.). Akademiya nauk SSSR, Sibirskoe otdelenie, Trudy Instituta geologii i geofiziki 313. [in Russian]

Apollonov, M.K. \& Chugaeva, M.N. 1983. Some trilobites from the Cambrian- Ordovician boundary interval from Batyrbai, Malyi Karatau, 66-90. In Apollonov, M.K., Bandaletov, S.M. \& Ivshin, N.K. (eds) The Lower Palaeozoic Stratigraphy and Palaeontology of Kazakhstan. Nauka, Kazakh SSR Publishing House, Alma-Ata. [in Russian]

Balashova, E.A. 1961. Some Tremadocian trilobites of Aktyube oblast, 102-145. In BALASHOVA, E.A., Keller, B.M., Lisogor, K.A., Obut, A.M., Rozman, H.S. \& Rukavishnikova, T.B. (eds) Ordovician of Kazakhstan, IV. Akademiya nauk SSSR, Trudy Geologicheskogo instituta 18. [in Russian]

Balseiro, D. \& MARENGo, L. 2008. Tremadocian trilobite assemblages from the Argentine Cordillera Oriental. A preliminary analysis, 33-40. In Rábano, I., Gozalo, R. \& GarcíaBellido, D. (eds) Advances in trilobite research, Cuadernos del Museo Geominero 9. Instituto Geológico y Minero de España, Madrid.

BAO, J.S. \& JAGO, J.B. 2000. Late Late Cambrian trilobites from near Birch Inlet, south-western Tasmania. Palaeontology 43(5), 881-917. DOI 10.1111/1475-4983.00154

BARTON, D.C. 1916. A revision of the Cheirurinae, with notes on their evolution. Washington University Studies, Scientific Series 3, 101-152.

Bergström, S.M., Chen, X., Guiterrez-Marco, J.C. \& Dronov, A. 2009. The new chronostratigraphic classification of the Ordovician System and its relation to major regional series and stages and to $\delta^{13} \mathrm{C}$ chemostratigraphy. Lethaia 42(1), 97-107. DOI 10.1111/j.1502-3931.2008.00136.x

Bergström, S.M. \& Löfgren, A. 2009. The base of the global Dapingian Stage (Ordovician) in Baltoscandia: conodonts, graptolites and unconformities. Earth and Environmental Science Transactions of the Royal Society of Edinburgh 99 (for 2008), 189-212.

Bergström, J., PÄrnaste, H. \& Zhou, Z.Y. 2013. Trilobites and biofacies in the Early-Middle Ordovician of Baltica and a brief comparison with the Yangtze Plate. Estonian Journal of Earth Sciences 62(4), 205-230.

DOI 10.3176/earth.2013.16

Bergström, S.M., Schmitz, B., Young, S.A. \& Bruton, D.L. 2010. The delta ${ }^{13} \mathrm{C}$ chemostratigraphy of the Upper Ordovician Mjøsa Formation at Furuberget near Hamar, southeastern Norway: Baltic, Trans-Atlantic and Chinese relations. Norwegian Journal of Geology 90, 65-78.

BEYRICH, E. 1846. Untersuchungen über Trilobiten. Zweite Stück als Fortsetzung zu der Abhandlung "Ueber einiger böhmische Trilbobiten”. 37 pp. Reimer, Berlin.

BiLLINGS, E. 1859. Description of some new species of trilobites from the Lower and Middle Silurian rocks of Canada. Canadian Naturalist and Geologist 4, 367-383.

Bogdanova, S.V., Bingen, B., Gorbatschev, R., Kheraskova, T.N., Kozlov, V.I., Puchkov, V.N. \& Volozh, Y.A. 2008. The East European Craton (Baltica) before and during the assembly of Rodinia. Precambrian Research 160, 23-45.

DOI 10.1016/j.precamres.2007.04.024

Bogolepova, O.K. \& GeE, D.G. 2004. Early Palaeozoic unconformity across the Timanides, NW Russia, 145-157. In GEE, D.G. \& Pease, V. (eds) The Neoproterozoic Timanide Orogen of Eastern Baltica. Geological Society of London, Memoirs 30.

Bondarev, V.I., Burskiy, A.Z., Koloskov, K.N. \& NeKhoroSHEVA, L.V. 1965. Early Ordovician fauna of the southern Novaya Zemlya and northern Pay-Khoy and its stratigaphical significance. Uchenye zapiski, Paleontologiya $i$ biostratigrafiya 10, 15-63. [in Russian]

Bondarev, V.I., Burskiy, A.Z., NeKhorosheva, L.V., Krasikov, E.M., Ravich, G.M., Khizhina, M.S. \& SobolevisKaya, R.F. 1970. General character of the reference section of the Ordovician in Pay-Khoy, Vaygach and south of Novaya Zemlya, 5-49. In BondAREV, V.I. (ed.) Reference section of the Ordovician on Pay-Khoy, Vaygach Island and Novaya Zemlya. Sevmorgeologia, Leningrad. [in Russian]

BrøgGER, W.C. 1882. Die Silurischen Etagen 2 und 3 im Kristianiagebiet und auf Eker, ihre Gliederung, Fossilien, Schichtenstörungen and Contactmetamorphosen. Universitätsprogramm für 2. Semester 1892. 375 pp. A.W. Brøgger, Kristiania.

BrøgGER, W.C. 1886. Über die Ausbildung des Hypostomes bei einigen skandinavischen Asaphiden. Bihang till Kungliga Svenska Vetenskaps-Akademiens Handlingar 11(3), 1-78.

BRøgGER, W.C. 1896. Über die Verbreitung der Euloma-Niobe Fauna (der Ceratopygenkalk Fauna) in Europa. Nyt Magazin for Naturvidenskab 36, 164-240.

Brongniart, A. 1822. Les Trilobites, 1-65. In Brongniart, A. \& Desmarest, A.-G. (eds) Histoire naturelle des crustacés fossiles, sous les rapports zoölogiques et géologiques. Paris \& Strasbourg.

Bruton, D. L. 1968. The trilobite genus Panderia from the Ordovician of Scandinavia and the Baltic areas. Norsk Geologisk Tiddskrift 48, 1-53.

BRUTON, D.L. \& HARPER, D.A.T. 1981. Brachiopods and trilobites of the early Ordovician serpentine Otta Conglomerate, south central Norway. Norsk Geologisk Tidsskrift 61, 151-181.

Bruton, D.L, Wright, A.J. \& Hamedi, M.A. 2004. Ordovician trilobites from Iran. Palaeontographica, Abteilung A - Palaozoologie, Stratigraphie 271, 111-149.

BurskiY, A.Z. 1966. Encrinuridae from Ordovician sediments of northern Pay-Khoy and Vaygach Island. Trudy Nauchnoissledovatelskogo instituta geologii Arktiki, Uchenye zapiski, Paleontologiya i biostratigrafiya 11, 79-84. [in Russian]

BurskiY, A.Z. 1970. Early Ordovician trilobites of the central Pay-Khoy, 96-138. In Bondarev, V.I. (ed.) Reference section of the Ordovician on Pay-Khoy, Vaygach Island and Novaya Zemlya. Sevmorgeologia, Leningrad. [in Russian]

Callaway, C. 1877. On a new area of Upper Cambrian rocks in 
South Shropshire, with a description of a new fauna. Quarterly Journal of the Geological Society of London 33, 652-672. DOI 10.1144/GSL.JGS.1877.033.01-04.37

Chugaeva, M.N. 1958. Ordovician trilobites of the Chu-Ili Mountains. Trudy Geologicheskogo instituta, Akademiya nauk SSSR 9, 5-138. [in Russian]

Chugaeva, M.N. 1973. Trilobites, 43-122. In Keller, B.M. (ed.) Biostratigraphy of the lower part of the Ordovician in the north-east of the USSR and biogeography of the uppermost Lower Ordovician. Transactions 213. [in Russian]

Cocks, L.R.M. \& Fortey, R.A. 1998. The Lower Palaeozoic margins of Baltica. GFF 120, 173-179.

DOI 10.1080/11035899801202173

Cocks, L.R.M. \& ToRsviK, T.H. 2002. Earth geography from 500 to 400 million years ago: a faunal and palaeomagnetic review. Journal of the Geological Society of London 159, 631-644. DOI 10.1144/0016-764901-118

Cocks, L.R.M. \& TorsviK, T.H. 2005. Baltica from the late Precambrian to mid-Palaeozoic times: The gain and loss of a terrane's identity. Earth-Science Reviews 72, 39-66.

DOI 10.1016/j.earscirev.2005.04.001

COOPER, B.N. 1953. Trilobites from the Lower Champlainian Formations of the Appalachian Valley. Geological Society of America Memoir 55, 1-69. DOI 10.1130/MEM55-p1

CoOper, G.A. 1930. Upper Ordovician and Lower Devonian stratigraphy and paleontology of Percé, Quebec. II. New species from the Upper Ordovician of Percé. American Journal of Science 20, 265-288, 365-392.

Dalman, J.W. 1827. Om Palaeaderna, eller de så kallade Trilobiterna. Kungliga Svenska Vetenskapsacademiens Handlingar 1826(2), 113-152, 226-294.

DEAN, W.T. 1960. The Ordovician trilobite faunas of south Shropshire, I. Bulletin of the British Museum (Natural History), Geology Series 4, 71-143.

DEAn, W.T. 1973. The lower Palaeozoic stratigraphy and faunas of the Taurus Mountains near Beysehir, Turkey III. The trilobites of the Sobova Formation (Lower Ordovician). Bulletin of the British Museum (Natural History) 24(5), 281-348.

DMitrovskAYA, Y.E. 1989. New data on stratigraphy of the lower Palaeozoic of the Moscow Syneclize. Part 2, Ordovician and Silurian. Byulletin' Moskovskogo obshchestva ispytateley prirody, Otdel' geologii 64(2), 82-94. [in Russian]

Dubinina, S.V. \& Ryazantsev, A.V. 2008. Conodont stratigraphy and correlation of the Ordovician volcanogenic and volcanogenic sedimentary sequences in the South Urals. Russian Journal of Sciences 10, ES5001.

DOI 10.2205/2008ES000302

EbBestad, J.O.R. 1999. Trilobites of the Tremadoc Bjørkåsholmen Formation in the Oslo Region, Norway. Fossils and Strata 47, 1-118.

EICHWALD, J.K.E. VON 1825. Geognostico-zoologicae per Ingriam marisque Baltici provincias nec non de Trilobitis observationes. 58 pp. Casani.

Ergaliev, G.H. 1980. Middle and Upper Cambrian trilobites of Malyi Karatau. 208 pp. Nauka KazSSR, Alma-Ata.

Ergaliev, G.H. 1983. Some Upper Cambrian and Lower Ordovician trilobites of Bolshoy Karatau and Ulutau, 35-66. In APOL-
Lonov, M.K., Bandaletov, S.M. \& Ivshin, N.K. (eds) The Lower Palaeozoic Stratigraphy and Palaeontology of Kazakhstan. Nauka, Kazakh SSR Publishing House, Alma-Ata. [in Russian]

FORTEY, R.A. 1980. The Ordovician trilobites of Spitsbergen. III. Remaining trilobites of the Valhallfonna Formation. Norsk Polarinstitutt Skrifter 171, 1-163.

ForTEY, R.A. 2009. A new giant asaphid trilobite from the Lower Ordovician of Morocco. Memoirs of the Association of Australasian Palaeontologists 37, 9-16.

ForTey, R.A. 2010. Trilobites of the genus Dikelokephalina from Ordovician Gondwana and Avalonia. Geological Journal 46(5), 405-415.

Fortey, R.A. \& Cocks, L.R.M. 2003. Palaeontological evidence bearing on global Ordovician-Silurian continental reconstructions. Earth-Science Reviews 61, 245-307.

DOI 10.1016/S0012-8252(02)00115-0

Fortey, R.A. \& Droser, M.L. 1999. Trilobites from the base of the type Whiterockian (Middle Ordovician) in Nevada. Journal of Paleontology 73(2), 182-201.

ForTEY, R.A. \& Hughes, N.C. 1998. Brood pouches in trilobites. Journal of Paleontology 72(4), 638-649.

Fortey, R.A. \& Owens, R.M. 1991. A trilobite fauna from the highest Shineton Shales in Shropshire, and the correlation of the latest Tremadoc. Geological Magazine 128(5), 437-464. DOI $10.1017 /$ S0016756800018616

Gee, D.G., Fossen, H., Henriksen, N. \& Higgins, A.K. 2008. From the Early Paleozoic Platforms of Baltica and Laurentia to the Caledonide Orogen of Scandinavia and Greenland. Episodes 31(1), 44-51.

Ghobadi Pour, M. 2006. Early Ordovician (Tremadocian) trilobites from Simeh-Kuh, Eastern Alborz, Iran, 93-118. In Bassett, M.G. \& Deisler, V.K. (eds) Studies in Palaeozoic Palaeontology, National Museum of Wales Geological Series 25.

Ghobadi Pour, M., Vidal, M. \& Hosseini-Nezhad, M. 2007. An Early Ordovician trilobite assemblage from the Lashkarak Formation, Damghan area, northern Iran. Geobios 40(4), 489-500. DOI 10.1016/j.geobios.2005.04.007

GoldFuss, A. 1843. Systematische übersichte der trilobiten und beschreibung einiger neuen arten derselben. Neues Jahrbuch für Mineralogie, Geognosie, Geologie und Pegrefaktenkunde 1843, 537-567.

Gorovtsova, N.I. \& Semenova, V.S. 1977. Upper Cambrian and Lower Ordovician trilobites from the Podkamennaya Tunguska River basin, 84-98. In Zhuravleva, I.T. \& Rozova, A.V. (eds) Biostratigraphy and fauna of the Upper Cambrian and the boundary strata (New data from the Asiatic part of the U.S.S.R.). Akademiya nauk SSSR, Sibirskoe otdelenie, Trudy Instituta geologii i geofiziki 313. [in Russian]

GreEN, J.M. 1832. Synopsis of the trilobites of North America. American Journal of Geology and Natural History 1(12), $558-560$.

Groom, T.T. 1902. On a new trilobite from the Dictyonemashales of the Malvern Hills. Geological Magazine 39, 70-73. DOI 10.1017/S0016756800184559

GüRICH, G. 1901. Ueber eine neue Lichas-Art aus dem Devon von 
Neu-Süd-Wales un über die Gattung Lichas überhaupt. Neues Jahrbuch für Mineralogie, Geologie und Paläontologie, Beil-agebände 14, 519-539.

Gutiérrez-Marco, J.C., SÁ, A.A., García-Bellido, D.C., RÁBANO, I. \& VALÉRIO, M. 2009. Giant trilobites and trilobite clusters from the Ordovician of Portugal. Geology 37, 443-446. DOI 10.1130/G25513A.1

Hammann, W., Álvaro, J.J. \& Vizcaïno, D. 2008. Early Ordovician trilobites from the Ibrian Chains, NE Spain: a tribute to Wolfgang Hammann, 415-419. In RÁBANo, I., Gozalo, R. \& GarCÍA-Bellido, D. (eds) Advances in trilobite research, Cuadernos del Museo Geominero 9. Instituto Geológico y Minero de España, Madrid.

Harper, D.A.T., Owen, A.W. \& Bruton, D.L. 2009. Ordovician life around the Celtic fringes: diversifications, extinctions and migrations of brachiopod and trilobite faunas at middle latitudes. Geological Society of London, Special Publications 325, 157-170. DOI 10.1144/SP325.8

HARRINGTON, H.J. 1938. Sobre las faunas del Ordoviciano Inferior del Norte Argentino. Revista del Museo de La Plata, Sección Paleont. New Series 1, 109-289.

Harrington, H.J. \& LeAnZA, A.F. 1957. Ordovician trilobites of Argentina. Special Publications, Department of Geology, University of Kansas 1, 1-276.

Hawle, I. \& CoRdA, A.J.C. 1847. Prodrom einer Monographie der böhmischen Trilobiten. Abhandlungen der Königlichen Böhmischen Gesellschaft der Wissenschaften 5. 176 pp. J.G. Calve, Prague.

Henningsmoen, G. 1957. The trilobite family Olenidae with description of Norwegian material and remarks on the Olenid and Tremadocian Series. Skrifter utgitt av Det Norske Videnskaps-Akademi i Oslo I, Matematisk-Naturvidenskapelig Klasse 1957(1), 1-303.

Howell, B.F. 1935. Cambrian and Ordovician trilobites from Hérault, southern France. Journal of Paleontology 9(3), 222-238.

Hupé, P. 1953. Classification des trilobites. Annales de Paléontologie 39, 61-168.

Ivshin, N.K. 1956. Upper Cambrian trilobites of Kazakhstan. Part 1. 119 pp. Izdatel'stvo Akademii nauk Kazakhskoy SSR, Alma-Ata. [in Russian]

Ivshin, N.K. 1962. Upper Cambrian trilobites of Kazakhstan. Part 2. 412 pp. Izdatel'stvo Akademii nauk Kazakhskoy SSR, Alma-Ata. [in Russian]

JAANUSSON, V. 1953. Untersuchungen über baltoskandische Asaphiden. I. Revision der mittel-ordovizischen Asaphiden des Siljan Gebietes in Dalarna. Arkiv för Mineralogi och Geologi 1(5-6), 377-464.

JAAnusson, V. 1954. Zur Morphologie und Taxonomie der Illaeniden. Arkiv för Mineralogi och Geologi 1(20), 545-83.

JAANUSSON, V. 1956. Untersuchungen über baltoskandische Asaphiden. III. Über die Gattungen Megistaspis n. nom. und Homalopyge n.gen. Bulletin of the Geological Institutions of the University of Uppsala 36, 59-78.

JAEKEL, O. 1909. Über die Agnostiden. Zeitschrift der Deutschen Geologischen Gesellschaft 61, 380-400.

JAGO, J.B. 1987. Idamean (Late Cambrian) trilobites from the
Denison Range, south-west Tasmania. Palaeontology 30(2), 207-231.

JELL, P.A. 1985. Tremadoc trilobites of the Digger Island Formation, Waratah Bay, Victoria. Memoirs of the Museum of Victoria $46(1-2), 53-88$.

Jell, P.A. \& Stait, B. 1985. Tremadoc trilobites from the Florentine Valley Formation, Tim Shea area, Tasmania. Memoirs of the Museum of Victoria 46(1-2), 1-34.

KLyUZhinA, M.L. 1985. Ordovician palaeogeography of Urals. 186 pp. Nauka, Moscow. [in Russian]

Kobayashi, T. 1934. The Cambro-Ordovician formations and faunas of South Chosen. Palaeontology. Part 2. Lower Ordovician faunas. Journal of the Faculty of Science, Imperial University of Tokyo, Section II 3(9), 521-585.

Kobayashi, T. 1936 On the Parabolinella fauna from Province Jujuy, Argentina with a note on the Olenidae. Japanese Journal of Geology and Geography 13, 85-102.

Kobayashi, T. 1939. On the agnostids, Part 1. Journal of the Faculty of Science, Imperial University of Tokyo, Section II 5(5), 70-198.

Kobayashi, T. 1940. Lower Ordovician fossils from Caroline Creek, near Latrobe, Mersey River district, Tasmania. Papers and Proceedings of the Royal Society of Tasmania 1939, $67-76$.

KoRINEVSKIY, V.G. 1989. The lower Ordovician reference sections of South Urals (terrigen facies). 66 pp. Scientific reports. Sverdlovsk. [in Russian]

Kuo, H.C., Duan, J.Y. \& AN, S.L. 1982. Cambrian-Ordovician boundary in the north China platform with descriptions of trilobites. Fourth International Symposium on the Ordovician System. Department of Geology, Changchun College of Geology, Changchun, China, 1-31.

LAMONT, A. 1948. Scottish dragons. The Quarry Manager's Journal 31, 531-535.

Lazarenko, N.P., Gogin, I.Y., Pegel, T.V. \& Abaimova, G.P. 2011. The Khos-Nelege section of the Ogon'or Formation: a potential candidate for the GSSP of Stage 10, Cambrian System. Bulletin of Geosciences 86(3), 555-568.

DOI 10.3140/bull.geosci.1270

Lazarenko, N.P. \& Pegel, T.V. 2001. Upper Cambrian levels of biostratigraphical correlation in the Khos-Nelege River reference section (northeastern flank of the Siberian Platform). Palaeoworld 13, 276-279.

Lermontova, E.V. \& Razumovskiy, N.K. 1933. On the ancient strata of the Urals (Lower Silurian and Cambrian at the outskirts of the Kidryasovo village in the South Urals). Notes of the Russian Mineralogical Society 62(1), 185-217. [in Russian]

LeVitskiy, E.S. 1962. On a new trilobite genus Cybelurus gen. nov. Izvestiya Vysshikh uchebnykh zavedenii, Geologiya i razvedka 7, 129-131. [in Russian]

Lisogor, K.A. 1961. Trilobites of the Tremadoc and adjacent strata of Kendyktas, 55-92. In Balashova, E.A., Keller, B.M., Lisogor, K.A., Obut, A.M., Rozman, H.S. \& RuKAvishnikova, T.B. (eds) Ordovician of Kazakhstan, IV. Akademiya nauk SSSR, Trudy Geologicheskogo instituta 18. [in Russian] 
Lisogor, K.A. 1977a. Biostratigraphy and trilobites of the Upper Cambrian and Tremadocian of Malyi Karatau (southern Kazakhstan), 197-265. In Zhuravleva, I.T. \& Rozova, A.V. (eds) Biostratigraphy and fauna of the Upper Cambrian and the boundary strata (New data from the Asiatic part of the U.S.S.R.)]. Akademiya nauk SSSR, Sibirskoe otdelenie, Trudy Instituta geologii i geofiziki 313. [in Russian]

LisoGoR, K.A. 1977b. Tremadocian trilobites from Malyi Karatau and the Khirgiz Mountains. Ezhegodnik Vsesoyuzhnogo paleontologicheskogo obshchestva 20, 105-127. [in Russian]

Lorenz, H., Gee, D.G., Männik, P. \& Proskurnin, V. 2008. Geology of the Severnaya Zemlya Archipelago and the North Kara Terrane in the Russian high Arctic. International Journal of Earth Science 97, 519-547. DOI 10.1007/s00531-007-0182-2

Loven, S.L. 1845. Svenska Trilobiter. Öfversigt af Kongliga Vetenskaps-Akademiens Förhandlingar 2, 46-56, 104-111.

Lu, Y.H., Zhang, W.T., Zhu, Z.L., Qian, Y.Y. \& Xiang, L.W. 1965. Trilobites of China. 766 pp. Science Press, Beijing. [in Chinese]

Lu, Y.H. 1975. Ordovician trilobite faunas of central and southwestern China. Palaeontologia Sinica, New Series B 11, 1-261. [in Chinese]

Ludvigsen, R. 1982. Upper Cambrian and Lower Ordovician Trilobite Biostratigraphy of the Rabbitkettle Formation, Western District of Mackenzie. 129 pp. Royal Ontario Museum, Toronto.

MaletZ, J. \& Ahlberg, P. 2011. The Lerhamn drill core and its bearing for the graptolite biostratigraphy of the Ordovician Tøyen Shale in Scania, southern Sweden. Lethaia 44, 350-368. DOI 10.1111/j.1502-3931.2010.00246.x

Mergl, M. 2006. Tremadocian trilobites of the Prague Basin, Czech Republic. Acta Musei nationalis Pragae, Series B historia naturalis 62(1-2), 1-70.

Metelkin, D.V., Kazansky, A.E., Vernikovsky, V.A., Gee, D.G. \& TorsviK, T.H. 2000. First paleomagnetic data on the Early Paleozoic rocks from the Severnaya Zemlya archipelago and their geodynamic interpretation. Geologiya i geofizika 41(12), 1767-1772. [in Russian]

Metelkin, D.V., Vernikovsky, V.A., Kazansky, A.Y., BogolePOVA, O.K. \& Gubanov, A.P. 2005. Paleozoic history of the Kara microcontinent and its relation to Siberia and Baltica: Paleomagnetism, paleogeography and tectonics. Tectonophysics 398, 225-243. DOI 10.1016/j.tecto.2005.02.008

Monti, D.S. \& Confalonieri, V.A. 2013. Phylogenetic analysis of the late Cambrian-early Ordovician genus Parabolinella Brøgger (Trilobita, Olenidae). Geological Journal 48(2-3), 156-169. DOI 10.1002/gj.1343

NASEDKINA, V.A. 1981. Ordovician conodonts of the western slope of the Urals and their stratigraphical importance. Synopsis of dissertation for the degree of Candidate of Geological and Mineralogical Sciences. 22 pp. Sverdlovsk. [in Russian]

Nikolaisen, F. \& Henningsmoen, G. 1985. Upper Cambrian and lower Tremadoc olenid trilobites from the Digermul peninsula, Finnmark, northern Norway. Norges Geologiske Undersøkelse, Bulletin 400, 1-49.

Ogienko, L.V. 1974. Trilobites of the Lower Ordovician,
109-133. In Ogienko, L.V., Byalyi, V.I. \& Kolosnitsyna, G.R. (eds) Biostratigraphy of Cambrian and Ordovician deposits in the southern Siberian Platform. Nedra, Moscow. [in Russian]

Ogienko, L.V. 1984. Phylum Arthropoda. Arthropods. Class Trilobita. Trilobites. The Lower Ordovician trilobites of the Siberian Platform, 57-72. In Kanygin, A.V., OBut, A.M. \& Volkhova, K.N. (eds) Ordovician of Siberian Platform. A palaeontological atlas. Akademiya nauk SSSR, Sibirskoe otdelenie, Trudy Instituta geologii i geofiziki 590. [in Russian]

O'Leary, N., White, N., Tull, S., Bashilov, V., Kuprin, V., Natapov, L. \& MacDonald, D. 2004. Evolution of the Timan-Pechora and South Barents Sea basins. Geological Magazine 141(2), 141-160.

DOI $10.1017 / \mathrm{S} 0016756804008908$

ÖPIK, A.A. 1937. Trilobiten aus Estland. Acta et Commentationes Universitatis Tartuensis A 32(3), 1-163.

Owens, R.M., Fortey, R.A., Cope, J.C.W., Rushton, A.W.A. \& BASSETT, M.G. 1982. Tremadoc faunas from the Carmarthen District, South Wales. Geological Magazine 119(1), 11-38. DOI 10.1017/S0016756800025632

PÄrnaste, H. \& Bergström, J. 2013. The asaphid trilobite fauna: Its rise and fall in Baltica. Palaeogeography, Palaeoclimatology, Palaeoecology 389, 64-77. DOI 10.1016/j.palaeo.2013.06.007

PÄrnaste, H., Bergström, J. \& Zhou, Z.Y. 2013. High resolution trilobite stratigraphy of the Lower-Middle Ordovician Öland Series of Baltoscandia. Geological Magazine 150(3), 509-518. DOI 10.1017/S0016756812000908

PÄrnaste, H., Popp, A. \& Owens, R.M. 2009. Distribution of the order Proetida (Trilobita) in Baltoscandian Ordovician strata. Estonian Journal of Earth Sciences 58, 10-23.

DOI 10.3176/earth.2009.1.02

PÄrnaste, H. \& Vitra, V. 2012. On the lower boundary of the Floian Stage in Estonia. Estonian Journal of Earth Sciences 61(1), 205-209. DOI 10.3176/earth.2012.4.02

Pegel, T.V. 2000. Evolution of trilobite biofacies in Cambrian basins of the Siberian Platform. Journal of Paleontology 74(6), 1000-1019.

DOI 10.1666/0022-3360(2000)074<1000:EOTBIC>2.0.CO;2

Peng, S.C. 1990a. Trilobites from the Nantsinkwan Formation of the Yangtze Platform. Beringeria 2, 3-53.

Peng, S.C. 1990b. Trilobites from the Panjazui Formation and the Madaoyu Formation in the Jiangnan Slope Belt. Beringeria 2, 55-171.

Peng, S.C. 1992. Upper Cambrian biostratigraphy and trilobite faunas of the Cili-Taoyuan area, north-western Hunan, China. Association of Australasian Palaeontologists, Memoir 13, 1-119.

Petrunina, Z.E. 1960. Trilobites, 409-433. In KhalfinA, L.L. (ed.) Biostratigraphy of the Palaeozoic in the Sayan Altai alpine region. I. Lower Palaeozoic. Trudy Sibirskogo Nauchno-issledovatelskogo instituta geologii, geofiziki i mineral'nogo syr'ya 19. [in Russian]

Petrunina, Z.E. 1966. Trilobites and stratigraphy of Tremadoc in western part of Sayano-Altai mountain range. Synopsis of dissertation for the degree of Candidate of Geological and Mineralogical Sciences. 30 pp. Alma-Ata. [in Russian] 
PetruninA, Z.E. 1973. New genera and species of Tremadocian trilobites from western Siberia, 59-68. In New knowledge of the geology and mineral resources of western Siberia 8. Tomsk University Publishing House, Tomsk. [in Russian]

Petrunina, Z.E. 1990. Some new Early Ordovician trilobites from the Altai-Sayan folded region, 21-58. In YolkIN, E.A. (ed.) Akademiya nauk SSSR, Sibirskoe otdelenie, Trudy Instituta geologii i geofiziki 770. [in Russian]

Poletaeva, O.K. 1960. New genera and species of Cambrian trilobites from western Siberia. Trudy Sibirskogo nauchnoissledovatel'skogo instituta geologii, geofiziki i mineral'nogo syr'ya 8, 50-76. [in Russian]

Poletaeva, O.K. 1977. Some trilobites from the Salair Complex (Orlin-aya Mountains, northeastern Salair), 152-161. In Zhuravleva, I.T. \& Rozova, A.V. (eds) Biostratigraphy and fauna of the Upper Cambrian and the boundary strata (New data from the Asiatic part of the U.S.S.R.). Akademiya nauk SSSR, Sibirskoe otdelenie, Trudy Instituta geologii i geofiziki 313. [in Russian]

Popov, L. \& Holmer, L.E. 1994. Cambrian-Ordovician lingulate brachiopods from Scandinavia, Kazakhstan, and South Ural Mountains. Fossils and Strata 35, 1-156.

Portlock, J.E. 1843. Report on the geology of the County of Londonderry, and parts of Tyrone and Fermanagh. 784 pp. A. Milliken, Dublin \& London.

Poulsen, C. 1952. Acerocarina, new name for Cyclognathus Linnarsson, non St. Hilaire. Quarterly Journal of the Geological Society of London 107, 441-442. DOI 10.1144/GSL.JGS.1951.107.01-04.22

Prantl, F. \& Přibyl, A. 1949 (for 1948). O nových nebo málo známých trilobitech českého ordoviku. Rozpravy České akademie věd a umění 58, 1-22. [in Czech; published in English as: Some new or imperfectly known Ordovician trilobites from Bohemia. Bulletin International de l'Académie tchèque des Sciences 49(8), 1-23.]

PrATT, B.R. 1988. An Ibexian (Early Ordovician) trilobite faunule from the type section of the Rabbitkettle Formation (southern Mackenzie Mountains, Northwest Territories). Canadian Journal of Earth Sciences 25, 1595-1607. DOI 10.1139/e 88-152

PřiBYL, A. 1949. On several new or little known trilobites of the Devonian of Bohemia. Věstník Českého geologického ústavu 24(5/6), 293-330.

PŘıBYL, A. \& VANĚK, J. 1980. Ordovician trilobites of Bolivia. Rozpravy Československé akademie věd, Řada matematických a přirodnich věd 90(2), 1-90.

PřıbYL, A., VANĚK, J. \& PeK, I. 1985. Phylogeny and taxonomy of Family Cheiruridae (Trilobita). Acta Universitatis Palackianae Olomucensis, Facultas rerum naturalium, GeographicaGeologica 83, 107-193.

Puchkov, V.N. 1991. Ordovician of the Sub-Polar Urals. 241 pp. Paleontologiya, Sverdlovsk. [in Russian]

RasetTi, F. 1943. New Lower Ordovician trilobites from Levis, Quebec. Journal of Paleontology 17(1), 101-104.

RasetTI, F. 1944. Upper Cambrian trilobites from the Levis Conglomerate. Journal of Paleontology 18(3), 229-258.
Raymond, P.E. 1905. Trilobites of the Chazy Limestone. Annals of the Carnegie Museum 3, 328-386.

RAYMOND, P.E. 1913. Subclass Trilobita, 629-729. In EASTMAN, C.R. (ed.) Text-book of paleontology. Adapted from the German of K.A. von Zittel. Second edition, Volume 1. MacMillan and Co., London.

RAYMOND, P.E. 1924. New Upper Cambrian and Lower Ordovician trilobites from Vermont. Proceedings of the Boston Society of Natural History 37, 389-466.

ReED, F.R.C. 1896. The fauna of the Keisley Limestone, Part. I. Quarterly Journal of the Geological Society of London 52, 407-437. DOI 10.1144/GSL.JGS.1896.052.01-04.22

REED, F.R.C. 1931. A review of the British species of the Asaphidae. Annals and Magazine of Natural History 10(7), 441-472. DOI 10.1080/00222933108673332

Richter, R. \& Richter, E. 1954. Die Trilobiten des Ebbe-Sattels und $\mathrm{zu}$ vergleichende Arten (Ordovizium, Gothlandium (Devon). Abhandlungen der Senckenbergischen Naturforschenden Gesellschaft 488, 1-76.

Robison, R.A. \& PANTOJA-AloR, J. 1968. Tremadocian trilobites from the Nochixthlán region, Oaxaca, Mexico. Journal of $\mathrm{Pa}$ leontology 42(3), 767-800.

Ross, R.J. 1951. Stratigraphy of the Garden City Formation in northeastern Utah, and its trilobite faunas. Peabody Museum of Natural History, Yale University, Bulletin 6, 1-161.

Ross, R.J. 1972. Fossils from the Ordovician Bioherm at Meiklejohn Peak, Nevada. United States Geological Survey Professional Papers 639, 1-43.

Rozova, A.V. 1960. Upper Cambrian trilobites of Salair. Trudy Instituta geologii i geofiziki, Sibirskoe otdelenie 5, 1-116. [in Russian]

Rozova, A.V. 1963. Biostratigraphic scheme for subdividing the Upper and the upper part of the Middle Cambrian of the north-western Siberian Platform, and new Upper Cambrian trilobites of the river Kulyumbe area. Geologiya i geofizika 9, 3-19. [in Russian]

Rozova, A.V. 1968. Biostratigraphic zonation and trilobites of the Upper Cambrian and Lower Ordovician of the north-western Siberian Platform. Akademiya nauk SSSR, Sibirskoe otdelenie, Trudy Instituta geologii i geofiziki 36, 1-196. [in Russian, English translation 1984, by Amerind Publishing Co., New Delhi].

Rozova, A.V. 1977. Some Upper Cambrian and Lower Ordovician trilobites of Rybnaya, Khantayka, Kureyka and Letnyaya river basins, 54-82. In Zhuravleva, I.T. \& Rozova, A.V. (eds) Biostratigraphy and fauna of the Upper Cambrian and the boundary strata (New data from the Asiatic part of the U.S.S.R.). Akademiya nauk SSSR, Sibirskoe otdelenie, Trudy Instituta geologii i geofiziki 313. [in Russian]

Rozova, A.V., Rozov, S.N. \& Dubatolova, Y.A. 1985. Stratigraphy and Fauna of the Ordovician of Northwestern Salair. 176 pp. Nauka, Moscow. [in Russian]

Rushton, A.W.A., Cocks, L.R.M. \& Fortey, R.A. 2002. Upper Cambrian trilobites and brachiopods from Severnaya Zemlya, Arctic Russia, and their implications for correlation and biogeography. Geological Magazine 139(3), 281-290. DOI $10.1017 / \mathrm{S} 0016756802006490$ 
RƯŽIČKA, R. 1926. Fauna vrstev Eulomových rudního ložiska u Holoubkova (v Ouzkém). Část I. Trilobiti. Rozpravy České akademie věd a umění 35(39), 1-26. [in Czech]

Ryazantsev, A.V., Dubinina, S.V., Kuznetsov, N.B. \& Belova, A.A. 2008. Ordovician Lithotectonic Complexes in Allochthons of the Southern Urals. Geotectonics 42(5), 368-395. DOI 10.1134/S0016852108050038

SALTER, J.W. 1853. On a few genera of Irish Silurian fossils. Association for the Advancement of Science 1852, 59-61.

Savelieva, G.N. \& Nesbitt, R.W. 1996. A synthesis of the stratigraphic and tectonic setting of the Uralian ophiolites. Journal of the Geological Society 153, 525-537.

DOI 10.1144/gsigs.153.4.0525

Schmidt, F. 1881. Revision der Ostbaltischen Trilobiten. Abtheilung I: Phacopiden, Cheiruriden und Encrinuriden. Mémoires de l'Académie Impériale des Sciences de St-Pétersbourg VII 30(1), 1-237.

SDZuY, K. 1955. Die Fauna der Leimitz-Schiefer (Tremadoc). Abhandlungen der Senckenbergischen Naturforschenden Gesellschaft 492, 1-74.

Sdzuy, K., Hammann, W. \& Villas, E. 2001. The upper Tremadoc fauna from Vogtendorf and the Bavarian Ordovician of the Frankenwald (Germany). Senckenbergiana lethaea 81(1), 207-261.

SHENG, X.F. 1934. Lower Ordovician trilobite fauna of Chekiang. Palaeontologia Sinica, N.S. B 3, 1-19.

Shergold, J.H. 1982. Idamean (Late Cambrian) trilobites, Burke River structural belt, western Queensland. Bureau of Mineral Resources, Geology and Geophysics, Bulletin 187, $\mathrm{vi}+69 \mathrm{pp}$.

Shergold, J.H., Feist, R. \& Vizcaïno, D. 2000. Early Late Cambrian trilobites of Australo-Sinian aspect from the Montagne Noire, southern France. Palaeontology 43(4), 599-632. DOI 10.1111/1475-4983.00142

Shergold, J.H., Laurie, J.R. \& Shergold, J.E. 2007. Cambrian and Early Ordovician trilobite taxonomy and biostratigraphy, Bonaparte Basin, Western Australia. Memoirs of the Association of Australasian Palaeontologists 34, 17-86.

Shergold, J.H. \& Sdzuy, K. 1984. Cambrian and early Tremadocian trilobites from Sultan Dağ, central Turkey. Senckenbergiana lethaea 65(1/3), 51-135.

Sivov, A.G. 1955. Cambrian Period. In KHAlfin, L.L. (ed.) Atlas of index forms of fossil faunas and floras of western Siberia 1. 501 pp. Gosgeoltekhizdat, Moscow.

Sohn, J.W. \& Chо, D.K. 2002. An uppermost Cambrian trilobite fauna from the Yongwol Group, Taebaeksan Basin, Korea. Ameghiniana 39(1), 59-76.

Stubblefield, C.J. \& Bulman, O.M.B. 1927. The Shineton Shales of the Wrekin district. Quarterly Journal of the Geological Society of London 83, 96-146. DOI 10.1144/GSL.JGS.1927.083.01-05.05

Terfelt, F., Ahlberg, P. \& Eriksson, M.E. 2011. Complete record of Furongian polymerid trilobites and agnostoids of Scandinavia. Lethaia 44(1), 8-14. DOI 10.1111/j.1502-3931.2009.00211.x

TimoKhin, A.V. 1989. The Lower Ordovician trilobites, 82-91. In Овит, А.M. (ed.) Ordovician of Siberian Platform. Fauna and stratigraphy of the Lena facial zone. Trudy Instituta geologii i geofiziki 751 .

TJERnVIK, T.E. 1956. On the Early Ordovician of Sweden, Stratigraphy and fauna. Bulletin of the Geological Institutions of the University of Uppsala 36, 107-284.

Torsvik, T.H. \& Andersen, T.B. 2002. The Taimyr fold belt, Arctic Siberia: timing of pre-fold remagnetisation and regional tectonics. Tectonophysics 352, 335-348.

DOI 10.1016/S0040-1951(02)00274-3

Tortello, M.F. \& Esteban, S.B. 2007. Trilobites de la Formación Volcancito (Miembro Filo Azul, Cámbrico Tardío) del Sistema de Famatina, La Rioja, Argentina: Aspectos sistemáticos y paleoambientales. Ameghiniana 44(3), 597-620.

UlRICH, E.O. 1930. Ordovician trilobites of the familyTelephidae and concerned stratigraphic correlations. Proceedings of the United States National Museum 76, 1-101.

DOI 10.5479/si.00963801.76-2818.1

VACCARI, E.N. \& WAISFELD, B.G. 2008. The Proto-Andean margin of Gondwana and accreted terranes: contrasting biogeographic signatures based on Late Cambrian - Early Ordovician trilobites, 403-409. In RÁbano, I., Gozalo, R. \& García-Bellido, D. (eds) Advances in trilobite research, Cuadernos del Museo Geominero 9. Instituto Geológico y Minero de España, Madrid.

Varganov, V.G., Antsygin, N.Y. \& Nasedkina, V.A. 1973. Stratigraphy and fauna of the Ordovician of the Middle Urals. 228 pp. Nedra, Moscow. [in Russian]

Varlamov, A.I., PaK, K.L. \& Rozova, A.V. 2006. The Upper Cambrian of the Chopko River Section, Norilsk Region, Northwestern Siberian Platform: Stratigraphy and Trilobites. Paleontological Journal 40 (Supplement 1), S1-S56. DOI 10.1134/S003103010607001X

Vizcaïno, D. \& Állvaro, J.J. 2003. Adequacy of the Lower Ordovician trilobite record in the southern Montagne Noire (France): biases for biodiversity documentation. Transactions of the Royal Society of Edinburgh, Earth Sciences 93, 1-9.

Vizcaïno, D., Álvaro, J.J. \& Lefebvre, B. 2001. The Lower Ordovician of the southern Montagne Noire. Annales de la Société géologique du Nord (2e série) 8, 213-220.

WAisfeld, B.G. \& VAcCARI, N.E. 2003. Chapter 9. Trilobites, 295-410. In Benedetto, J.L. (ed.) Ordovician fossils of Argentina. Secretaría de Ciencia y Tecnología, Universidad Nacional de Córdoba.

WalcotT, C.D. 1925. Cambrian and Lower Ozarkian trilobites. Smithsonian Miscellaneous Collections 75, 61-146.

WARDER, J.A. 1838. New trilobites. American Journal of Science 34(1), 377-380.

Weber, V.N. 1948. Silurian trilobites of Soviet Union. 1. The Lower Silurian trilobites. Monografii po paleontologii SSSR 69, 1-111. [in Russian]

Westergård, A.H. 1939. In SAndegren, R., Asklund, B. \& Westergård, A.H. (eds) Beskrivning till kartbladet Gävle. Sveriges Geologiska Undersökning Series Aa 178.

Whittington, H.B. 1963. Middle Ordovician trilobites from Lower Head, western Newfoundland. Bulletin of the Museum of Comparative Zoology, Harvard University 129, 1-118.

Whittington, H.B. 1965. Trilobites of the Ordovician Table 
Head Formation, western Newfoundland. Bulletin of the $\mathrm{Mu}$ seum of Comparative Zoology, Harvard 132, 275-442.

Zhen, Y.Y. \& Percival, I. 2003. Ordovician conodont biogeography - reconsidered. Lethaia 36(4), 357-369.

DOI 10.1080/00241160310006402

Zhou, Z.Y., Bergström, J., Zhou, Z.Q., YuAN, W.W. \& Zhang, Y.B. 2011. Trilobite biofacies and palaeogeographic development in the Arenig (Ordovician) of the Yangtze block, China. Palaeoworld 20, 15-45. DOI 10.1016/j.palwor.2010.12.005

Zhou, Z.Y. \& Zhang, J. L. 1984. Uppermost Cambrian and lowest Ordovician trilobites of North and Northeast China, 63-194. In Nanjing Institute of Geology and Palaeontol-
OGY (ed.) Stratigraphy and Palaeontology of Systemic Boundaries in China, Cambrian - Ordovician Boundary 2. Anhui Science and Technology Publishing House, Hefei.

Zhou, Z.Y. \& Zhen, Y.Y. 2008. Trilobite Record of China. 402 pp. Science Press, Beijing.

Zhu, X.J. \& Peng, S.C. 2006. Eoshumardia (Trilobite, Cambrian), a junior synonym of Koldinioidia. Alcheringa 30(2), 183-189. DOI 10.1080/03115510608619312

ŻYLIŃSKA, A. 2002. Stratigraphic and biogeographic significance of Late Cambrian trilobites from Łysogóry (Holy Cross Mountains, central Poland). Acta Geologica Polonica 52(2), 217-238. 